\title{
Ephrin-B2 expression critically influences Nipah virus infection independent of its cytoplasmic tail
}

\author{
Lena Thiel ${ }^{1}$, Sandra Diederich ${ }^{1}$, Stephanie Erbar ${ }^{1}$, Dennis Pfaff ${ }^{2}$, \\ Hellmut G Augustin ${ }^{2}$ and Andrea Maisner*1
}

\begin{abstract}
Address: ${ }^{1}$ Institute of Virology, Philipps University of Marburg, Marburg, Germany and ${ }^{2}$ Joint Research Division Vascular Biology, Medical Faculty Mannheim, University of Heidelberg (CBTM), and German Cancer Research Center (DKFZ), Heidelberg, Germany

Email: Lena Thiel - thiellen@staff.uni-marburg.de; Sandra Diederich - sandra.diederich@staff.uni-marburg.de; Stephanie Erbar - Erbar@students.uni-marburg.de; Dennis Pfaff - Dennis.Pfaff@unibas.ch; Hellmut G Augustin - h.augustin@dkfzheidelberg.de; Andrea Maisner* - maisner@staff.uni-marburg.de

* Corresponding author
\end{abstract}

Published: 24 December 2008

Virology Journal 2008, 5:163 doi:10.1186/1743-422X-5-163

This article is available from: http://www.virologyj.com/content/5/I//63

(C) 2008 Thiel et al; licensee BioMed Central Ltd.

This is an Open Access article distributed under the terms of the Creative Commons Attribution License (http://creativecommons.org/licenses/by/2.0), which permits unrestricted use, distribution, and reproduction in any medium, provided the original work is properly cited.
Received: II December 2008

Accepted: 24 December 2008

\begin{abstract}
Background: Cell entry and cell-to-cell spread of the highly pathogenic Nipah virus (NiV) requires binding of the NiV G protein to cellular ephrin receptors and subsequent NiV F-mediated fusion. Since expression levels of the main NiV entry receptor ephrin-B2 (EB2) are highly regulated in vivo to fulfill the physiological functions in axon guidance and angiogenesis, the goal of this study was to determine if changes in the EB2 expression influence NiV infection.
\end{abstract}

Results: Surprisingly, transfection of increasing EB2 plasmid concentrations reduced cell-to-cell fusion both in cells expressing the NiV glycoproteins and in cells infected with NiV. This effect was attributed to the downregulation of the NiV glycoproteins from the cell surface. In addition to the influence on cell-to-cell fusion, increased EB2 expression significantly reduced the total amount of $\mathrm{NiV}$-infected cells, thus interfered with virus entry. To determine if the negative effect of elevated EB2 expression on virus entry is a result of an increased EB2 signaling, receptor function of a tailtruncated and therefore signaling-defective $\triangle \mathrm{CEB} 2$ was tested. Interestingly, $\triangle \mathrm{cEB} 2$ fully functioned as $\mathrm{NiV}$ entry and fusion receptor, and overexpression also interfered with virus replication.

Conclusion: Our findings clearly show that EB2 signaling does not account for the striking negative impact of elevated receptor expression on $\mathrm{NiV}$ infection, but rather that the ratio between the NiV envelope glycoproteins and surface receptors critically influence cell-to-cell fusion and virus entry.

\section{Background}

Nipah virus (NiV) was isolated in 1999 after an outbreak of severe respiratory illness in pigs and fatal encephalitis among pig farmers in Malaysia and Singapore [1,2]. Together with the closely related Hendra virus (HeV), NiV forms the new genus henipavirus within the Paramyxoviridae family $[3,4]$. With their exceptional wide host range, their zoonotic potential and their ability to cause fatal diseases in animals and humans, henipaviruses differ from all other known paramyxoviruses and are classified as Biosafety Level 4 (BSL4) pathogens. Fruit bats of the genus Pteropus have been identified as natural NiV reservoir. Besides bats, many other mammalian species such as pigs, horses, dogs, cats or humans can be infected [5-8]. During 
the first outbreak beginning in $1998, \mathrm{NiV}$ was transmitted from bats to pigs, and then to humans. In more recent outbreaks in Bangladesh which were characterized by higher case fatality rates near $70 \%$ and rare human-tohuman transmissions, there was no link to infected livestock or domestic animals. Here, NiV was likely transmitted to humans by date palm sap contaminated by bat secretions [9-11].

Infection of endothelial cells is a hallmark of NiV infection in animals and humans. Significant involvement of blood vessels in the central nervous system (CNS), lung, heart and kidney was observed in all infections. In humans, the severe damage of the microvasculature of the CNS is thought to be the basis for the development of the $\mathrm{NiV}$ encephalitis which often leads to coma and death within three to thirty days $[12,13]$. Typically, small arteries, arterioles, capillaries and venules in the brain showed evidence of vasculitis and thrombosis with frequent adjacent necrosis and hemorrhage. Syncytial or multinucleated giant endothelial cells were seen in blood vessels of various organs, and viral inclusions were found in endothelial cells as well as in brain parenchymal cells and neurons near vasculitic vessels or necrotic plaques [13]. As extensive viral replication in the CNS is assumed to be an important factor for high mortality [14], efficient NiV entry and spread from infected cells in the brain is likely crucial for the outcome of infection.

Successful NiV entry into host cells requires the concerted action of the two viral envelope glycoproteins F and G. After binding of the attachment protein $G$ to suitable receptors on the cell surface, the fusion protein $\mathrm{F}$ in cooperation with the $G$ protein promotes fusion of the viral envelope and the plasma membrane leading to virus entry. As with most paramyxoviruses, virus entry occurs at the cell surface and does not require receptor-mediated endocytosis [15]. After productive NiV replication, newly synthesized $\mathrm{F}$ and $\mathrm{G}$ proteins are expressed on the surface of the infected cell, and can trigger cell-to-cell fusion with receptor-bearing neighboring cells resulting in the formation of multinucleated syncytia [16]. To fulfill its function in fusion promotion during virus entry and cell-to-cell fusion, the NiV F protein must be proteolytically activated by cellular cathepsin $\mathrm{L}$ within an acidic endosomal compartment, before it is expressed on the cell surface and is incorporated into cell-free virus particles [15,17-19].

Ephrin-B2 (EB2) is known to act as main entry receptor for $\mathrm{NiV}[20,21]$, and its expression on endothelial cells, smooth muscle cells and neurons [22-26] is highly consistent with the known tropism of NiV infection in vivo [13]. Besides EB2, ephrin-B3 can function as alternate receptor and is likely used in brain regions where EB2 is not expressed $[27,28]$. EB2 is a transmembrane-anchored ligand of the receptor tyrosine kinases EphB2, EphB3 and EphB4. Interactions of Eph receptors with EB2 can trigger a wide array of cellular responses including cell adhesion, boundary formation and repulsion, and thus play a critical role in embryonic patterning, axon guidance, blood vessel remodeling and lymphangiogenesis [25,29-31]. Important for these physiological functions is the tight regulation of protein levels and an asymmetric distribution of ephrins and Eph receptors, for instance the asymmetrical arteriovenous expression of EB2 and EphB4 $[23,26,32,33]$. Eph-ephrin binding and clustering triggers a bi-directional signaling that is mediated by interactions of the cytoplasmic tails with cytosolic factors [30]. In EB2, activation of the signaling cascade depends on the C-terminal 33 amino acids, and EB2 knockout or truncation of just the catalytic cytoplasmic domain resulted in a signaling-defective EB2 which had lost its ability to promote vascular remodeling [34,35].

Since the expression levels of EB2 are highly regulated in vivo $[23,32,33]$ and levels of viral entry receptors can be crucial for efficient virus entry and replication, the goal of this study was to determine if changes in EB2 receptor expression on the surface of $\mathrm{NiV}$ target cells influence $\mathrm{NiV}$ infection. We found that an overexpression of EB2 interfered with virus entry and NiV glycoprotein-mediated cellto-cell fusion in F and G-transfected cells as well as in NiVinfected cells. Whereas the reduction in syncytia formation can be explained by the downregulation of the $\mathrm{NiV}$ glycoproteins from the cell surface, inhibition of virus entry is likely due to an oversupply of EB2 surface receptors interfering with efficient virus-cell fusion and subsequent NiV entry. Fusion assays and infection studies in cells expressing a tail-truncated and thus signaling-defective EB2 revealed that the catalytic cytoplasmic domain of EB2 is not involved in this process.

\section{Results \\ Increasing surface expression levels of the NiV receptor EB2 interfere with NiV glycoprotein-mediated cell-to-cell fusion}

A correlation of expression levels of cell-surface receptors and infection efficiency has been shown for many different viruses. Increased receptor expression had either a beneficial effect on virus replication or had no effect [3643]. To determine the influence of differences in receptor expression on $\mathrm{NiV}$ replication, we first analyzed the effect on glycoprotein-mediated fusion in the absence of a $\mathrm{NiV}$ infection. To monitor EB2 surface expression, EB2-negative HeLa cells were transfected with increasing amounts of EB2 plasmid DNA (pCAGGS-EB2), and were analyzed at $24 \mathrm{~h}$ post transfection (p.t.) by immunostaining (Fig. 1A) and FACS analysis (Fig. 1B). For immunofluorescence staining, living cells were incubated with recombinant EphB4/Fc. Surface-bound EphB4/Fc was then detected 
A.
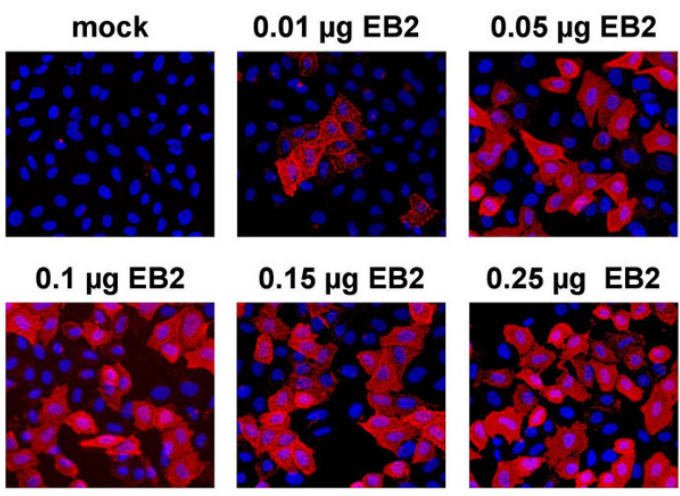

\section{$0.5 \mu \mathrm{g}$ EB2}

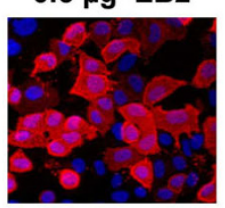

$1.0 \mu \mathrm{g}$ EB2
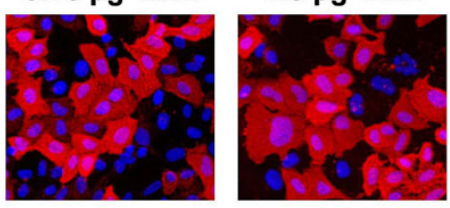

B.
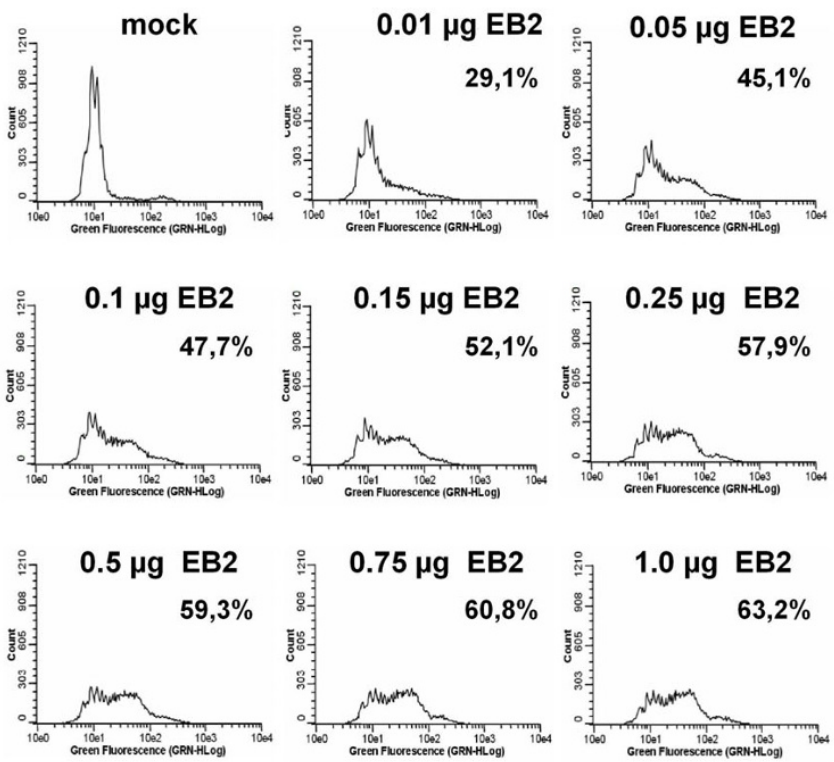

C.
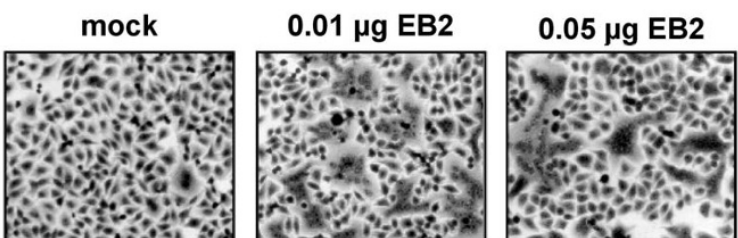

D.
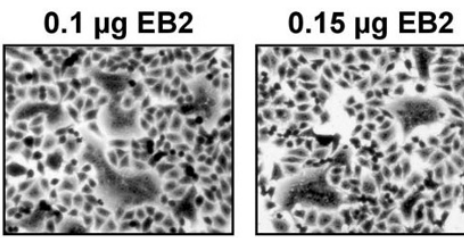

$0.25 \mu \mathrm{g}$ EB2
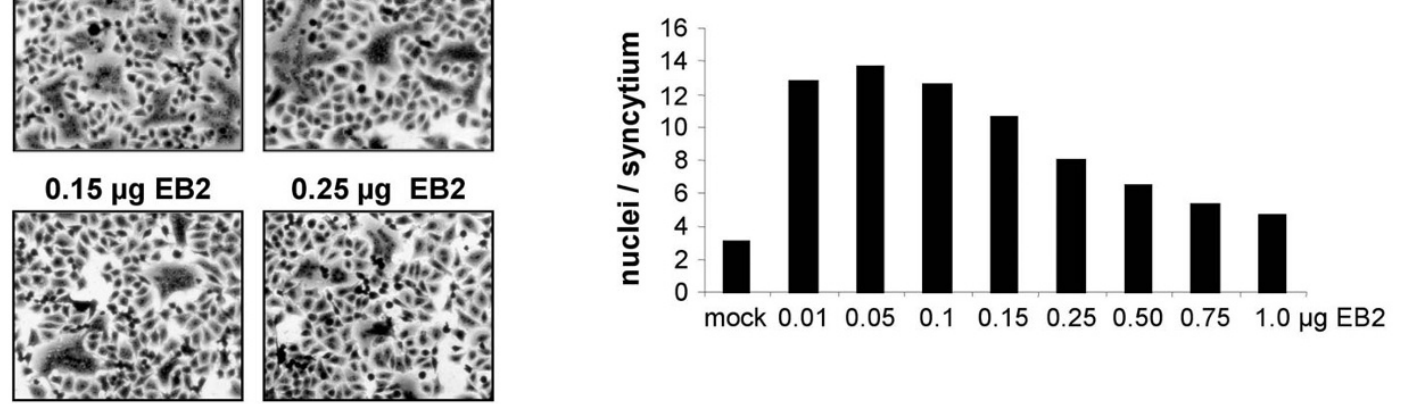

$0.75 \mu \mathrm{g}$ EB2
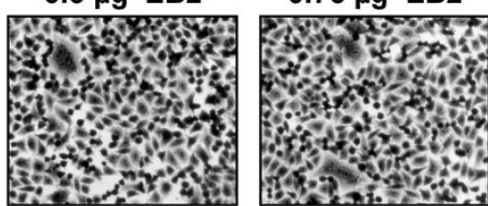

$1.0 \mu \mathrm{g}$ EB2

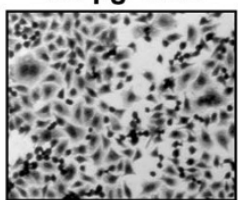

Figure I

EB2 surface expression and NiV glycoprotein-mediated cell-to-cell fusion in HeLa cells transfected with different amounts of pCAGGS-EB2. (A) Receptor-negative HeLa cells were transfected with the indicated quantities of an EB2encoding PCAGGS vector. At 24 h p.t., immunostaining was performed using recombinant EphB4/Fc and rhodamine-conjugated secondary antibodies. Nuclei were visualized by DAPI staining. (B) HeLa cells expressing different amounts of EB2 were incubated with an EB2-specific antibody followed by FITC-conjugated secondary antibodies. FACS analysis was performed at 24 h p.t. (C) HeLa cells were cotransfected with constant quantities of plasmids carrying the NiV $F$ and $G$ genes and the indicated amounts of pCAGGS-EB2. To visualize cell-to-cell fusion, cells were fixed and incubated with Giemsa staining solution at $24 \mathrm{~h}$ p.t.. Representative microscopic fields were photographed. (D) Syncytium formation of HeLa cells expressing different amounts of EB2 as shown in panel $C$ was quantified by counting and averaging the number of nuclei per syncytium of twenty randomly chosen syncytia. 
with a rhodamine-conjugated anti-human IgG antibody. FACS analysis of surface-expressed EB2 was performed using an EB2-specific antibody and FITC-conjugated antigoat secondary antibodies. As shown in Fig. 1A and 1B, the number of EB2-positive cells raised with increasing quantities of EB2 DNA. In the sample transfected with 1 $\mu$ p pCAGGS-EB2, $63.2 \%$ of the cells expressed EB2 on the cell surface. The mean fluorescence values, thus the mean receptor densities, were the same in all EB2-transfected cells indicating that cultures with more EB2-positive cells contained an increased total number of cells with higher EB2 expression levels, but maximal EB2 surface expression levels were not upregulated by transfection of more plasmid DNA.

To analyze the ability of cell cultures transfected with different EB2 plasmid concentrations to support NiV glycoprotein-mediated cell-to-cell fusion, constant and optimized ratios of NiV F and G protein encoding plasmids were cotransfected, and syncytia formation was monitored at 24 h p.t. by staining with Giemsa solution (Fig. 1C). Since HeLa cells do not express endogenous EB2, mock-transfected HeLa cells did not support any NiV glycoprotein-specific fusion (Fig. 1C, mock). As expected, EB2 transfection was required to render cells susceptible for cell-to-cell fusion. However, pronounced syncytia formation was only seen in cells transfected with low amounts of pCAGGS-EB2, higher amounts interfered with efficient cell-to-cell fusion. When we determined the mean size of syncytia by counting and averaging the number of nuclei per syncytium (Fig. 1D), we found the largest syncytia (14 nuclei) in HeLa cells transfected with only $0.05 \mu \mathrm{g}$ pCAGGS-EB2. Then, the size decreased stepwise with increasing DNA amounts down to 4.9 nuclei per syncytium in cells transfected with $1 \mu \mathrm{g}$ pCAGGS-EB2.

To test if differences in EB2 expression also affect syncytium induction in NiV permissive cells expressing endogenous EB2, cotransfection of the NiV glycoprotein genes in addition to various amounts of pCAGGS-EB2 was performed in Vero cells. As anticipated, NiV F and G induced syncytium formation in mock-transfected cells (Fig. 2A, mock). Supplemental expression of exogenous EB2, even at the lowest concentration tested $(0.1 \mu \mathrm{g} D N A)$, resulted in decreased cell-to-cell fusion (Fig. 2A and 2B). In accordance with HeLa cells, EB2 overexpression in Vero cells clearly led to downregulation of $\mathrm{NiV}$ glycoproteininduced syncytia formation. FACS analysis to quantify EB2 expression levels in transfected Vero cells again showed that with rising amounts of EB2 DNA an increasing percentage of Vero cells (up to $40 \%$ in cells transfected with $1 \mu \mathrm{g}$ DNA) expressed EB2 at higher surface densities (data not shown). The mean fluorescence values in this cell population expressing additional plasmid-encoded EB2 was about 10-fold higher than in Vero cells express- ing endogenous EB2 only (mock transfected cells). To exclude that these higher EB2 expression levels have a general downregulating effect on paramyxovirus cell-to-cell fusion, we investigated the effect of EB2 overexpression on syncytium formation caused by the measles virus Edmonston $\left(\mathrm{MV}_{\mathrm{Edm}}\right)$ glycoproteins $\mathrm{F}$ and $\mathrm{H} . \mathrm{MV}_{\mathrm{Edm}}$ does not bind to EB2 but uses CD46 as entry receptor which is also endogenously expressed in Vero cells [44]. Cells were transfected with the $M V_{\mathrm{Edm}} \mathrm{F}$ and $\mathrm{H}$ genes together with different amounts of pCAGGS-EB2 and syncytia formation was analyzed at 15 h p.t.. In contrast to what we had observed for NiV, EB2 overexpression had no negative effect on $\mathrm{MV}_{\mathrm{Edm}}$ glycoprotein-mediated cell-to-cell fusion (Fig. 2C). This demonstrates that higher amounts of EB2 do not generally interfere with paramyxoviral glycoprotein-induced fusion but specifically inhibit NiV F- and Gmediated syncytia formation. When we expressed the NiV $F$ and $G$ protein in the presence of increasing amounts of CD46 we again did not see any effect on syncytia formation (Fig. 2D). Therefore, the downregulating effect on $\mathrm{NiV}$ glycoprotein-mediated fusion by EB2 is specific.

\section{EB2 overexpression can downregulate surface expression of the NiV glycoproteins}

To determine if EB2 overexpression affects surface expression of the NiV F or G protein, Vero cells were cotransfected with constant amounts of plasmids encoding the $\mathrm{NiV}$ glycoproteins $\mathrm{F}$ and $\mathrm{G}$ in addition to varying amounts of pCAGGS-EB2. At 24 h p.t., cells were surface biotinylated followed by immunoprecipitation of $\mathrm{F}$ and $\mathrm{G}$ proteins. After separation by SDS-PAGE and blotting to nitrocellulose, surface expressed NiV glycoproteins were detected by IRDye 800-conjugated streptavidin. As shown in Fig. 3A and 3B, EB2 overexpression reduced the expression levels of $\mathrm{F}$ and $\mathrm{G}$ protein on the cell surface in a concentration-dependent manner. The finding that surface expression of the MV glycoproteins $\mathrm{F}$ and $\mathrm{H}$ was not influenced by EB2 transfection (Fig. 3C) clearly suggests that surface downregulation of $\mathrm{NiV}$ glycoprotein complexes is due to specific interactions with EB2.

\section{Increased EB2 surface expression interferes with productive NiV infection}

To analyze the effects of additional EB2 expression in the context of a NiV infection, Vero cells were transfected with different amounts of the EB2-encoding plasmid, transferred to the BSL4 facility and subsequently infected with $\mathrm{NiV}$ at a multiplicity of infection (MOI) of 1 . NiV-positive cells were stained by indirect immunofluorescence analysis at $24 \mathrm{~h}$ post infection (p.i.) to reveal the size and the number of syncytia. To quantify virus production, virus titers in the supernatant were determined by the $\mathrm{TCID}_{50}$ method. For immunostaining, NiV-infected cells were fixed and incubated with a NiV-specific guinea pig antiserum and rhodamine-conjugated secondary antibodies. 
A.
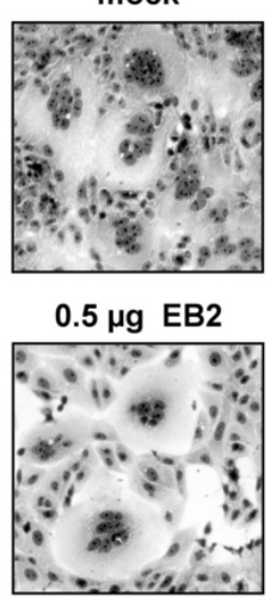

c.

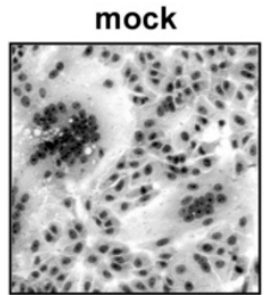

$0.5 \mu \mathrm{g}$ EB2

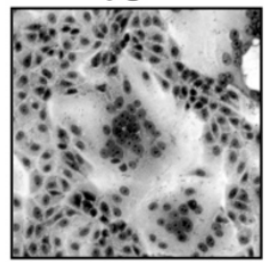

$0.1 \mu \mathrm{g}$ EB2

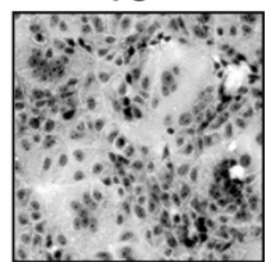

$0.75 \mu \mathrm{g}$ EB2

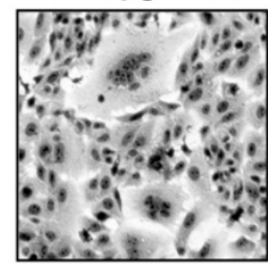

$0.25 \mu \mathrm{g}$ EB2

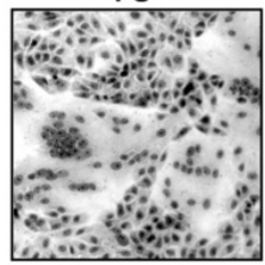

$1.0 \mu \mathrm{g}$ EB2

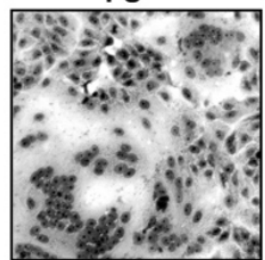

$0.25 \mu \mathrm{g}$ EB2

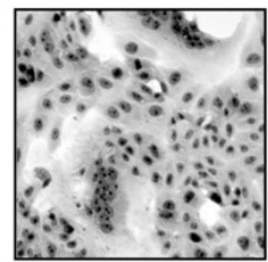

$1.0 \mu \mathrm{g}$ EB2

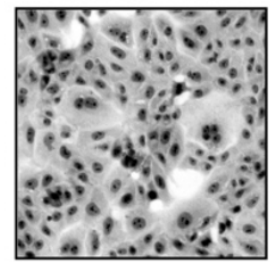

B.

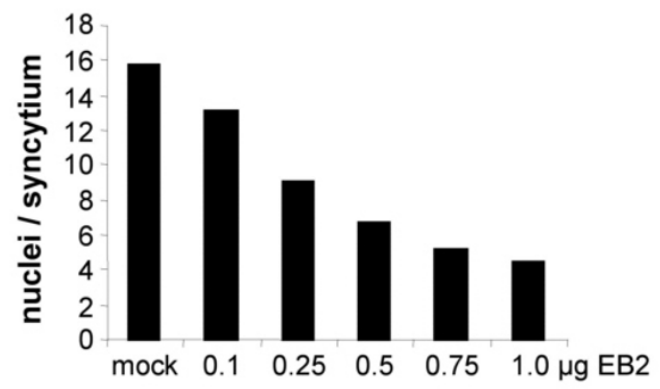

D.
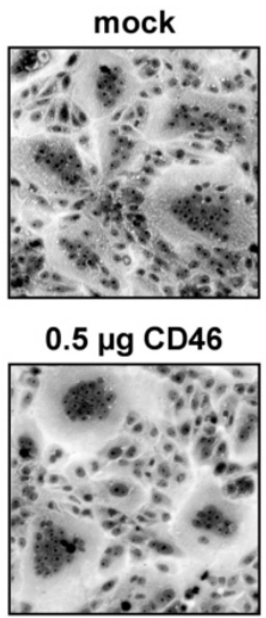

$0.1 \mu \mathrm{g} \mathrm{CD} 46$

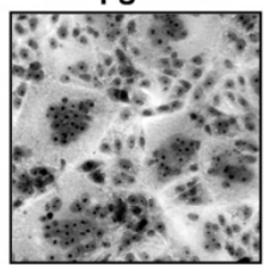

$0.75 \mu \mathrm{g}$ CD46

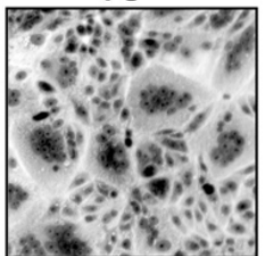

$0.25 \mu \mathrm{g}$ CD46

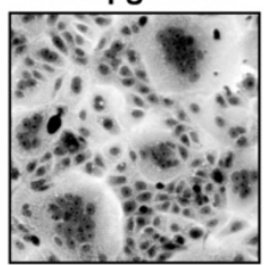

$1.0 \mu \mathrm{g}$ CD46

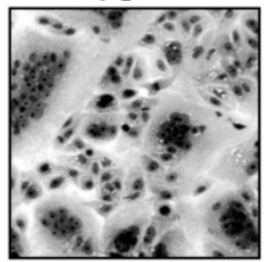

\section{Figure 2}

NiV and MV glycoprotein-mediated cell-to-cell fusion in Vero cells overexpressing different amounts of EB2 or CD46. (A) Vero cells were cotransfected with plasmids encoding the NiV F and G protein and increasing amounts of PCAGGS-EB2. Cell-to-cell fusion was visualized by Giemsa staining at 24 h p.t.. (B) Quantification of syncytium formation was performed as described in the legend to Fig. ID. (C) Cells transfected with constant amounts of the MV glycoproteins and the indicated amounts of EB2 were Giemsa stained at $15 \mathrm{~h}$ p.t.. (D) Cells were transfected with constant amounts of plasmids encoding NiV F and G proteins and different amounts of plasmids encoding the CD46 gene. At 24 h p.t., syncytium formation was visualized by Giemsa staining.

Cell nuclei were counterstained with DAPI. Merged pictures of the rhodamine and DAPI fluorescence channels are shown in Fig. 4A and demonstrate that all Vero cell cultures transfected with different amounts of pCAGGSEB2 could be infected with NiV. However, the number and size of syncytia appeared to be reduced in cells transfected with pCAGGS-EB2. This was confirmed by determining the average size of the NiV-induced syncytia (Fig. 4B). Whereas syncytia in mock-transfected cells contained about 50 nuclei in average, cells transfected with $0.25 \mu \mathrm{g}$, $0.5 \mu \mathrm{g}$ or $1 \mu \mathrm{g}$ of EB2 plasmid DNA produced syncytia with 22, 19 or 15 nuclei, respectively. To evaluate if differences in EB2 expression also affect virus entry, the total number of syncytia in each sample was counted and was also found to be reduced in EB2-transfected cells (Fig. $4 \mathrm{C}$ ). Since one syncytium originates from one initially infected cell, this finding clearly indicates that not only NiV-mediated cell-to-cell fusion but also virus entry is impaired in Vero cells overexpressing EB2. In agreement with the decreased total number of infected cells and the less efficient spread via cell-to-cell fusion, the amount of infectious NiV particles released into the cell supernatant 


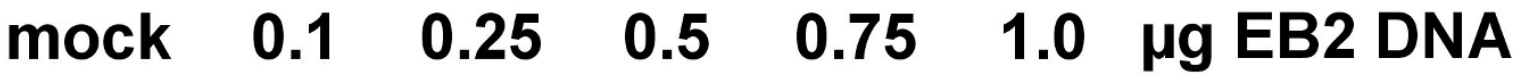

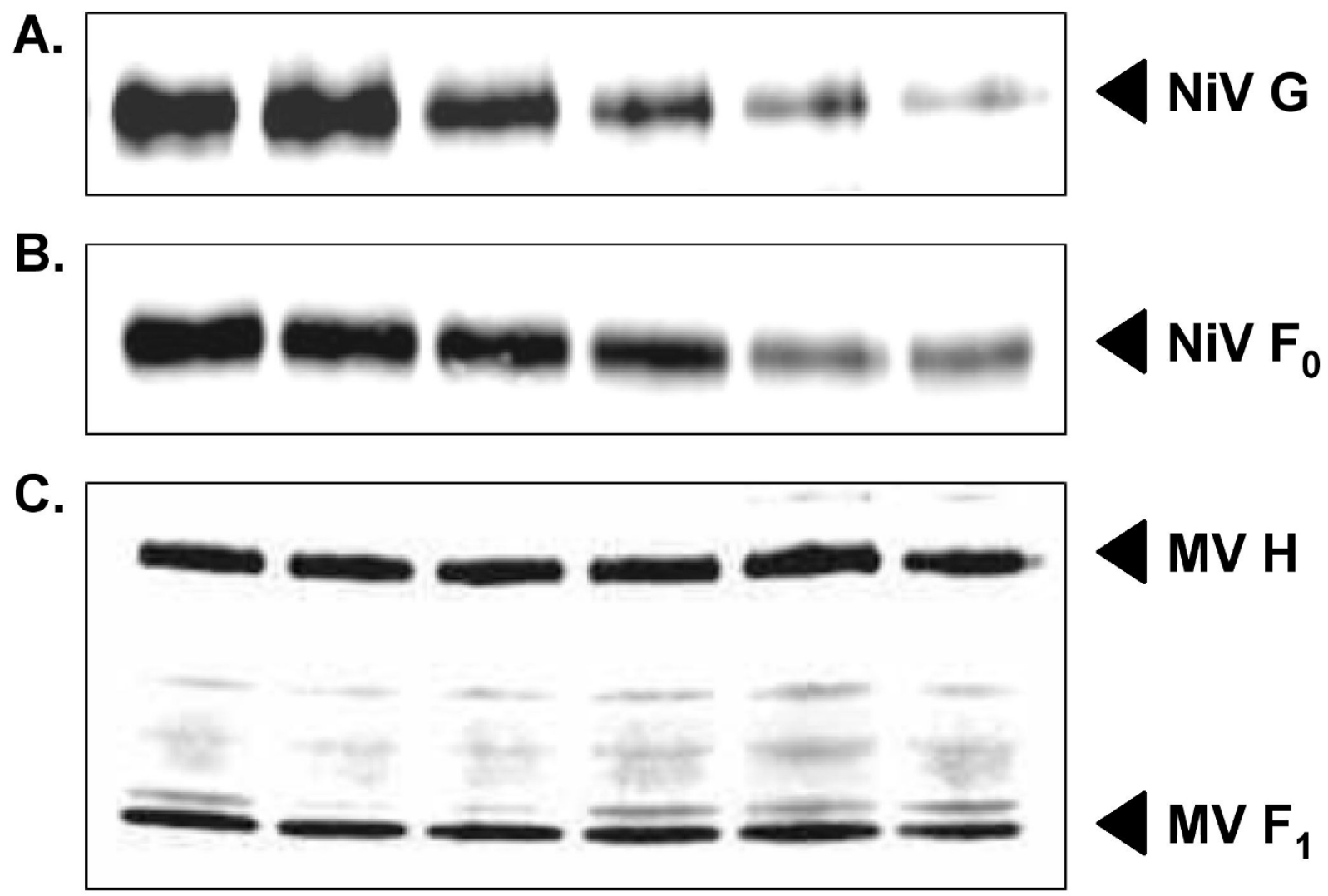

Figure 3

Surface expression of $\mathrm{NiV}$ and $\mathrm{MV}$ glycoproteins in the presence of increasing amounts of EB2. Vero cells were cotransfected with constant amounts of NiV F- or G-encoding plasmids and the indicated amounts of pCAGGS-EB2. At $24 \mathrm{~h}$ p.t., cells were surface biotinylated and lysed. (A) Immunoprecipitation of NiV G was carried out using a polyclonal NiV antiserum. After separation on a $12 \%$ SDS gel under reducing conditions and blotting to nitrocellulose, surface-biotinylated G proteins were detected by IRDye 800-conjugated streptavidin using a LiCor-Odyssey imager. (B) NiV F was immunoprecipitated with an F-specific antiserum, separated by SDS-PAGE under non-reducing conditions and further processed as described above. $(C)$ Vero cells were cotransfected with constant amounts of plasmids encoding the MV $F$ and $H$ proteins and the different amounts of pCAGGS-EB2. Immunoprecipitation of the MV glycoproteins was carried out using F- and $\mathrm{H}$-specific antibodies. After separation by SDS-PAGE under reducing conditions and blotting, proteins were detected as described above.

was also drastically diminished. Virus titers were reduced by more than 100-fold (Fig. 4D). To examine if inhibition of infection by EB2 overexpression is specific for NiV, control studies were performed with $\mathrm{MV}_{\mathrm{Edm}}$. Vero cells transfected with various quantities of pCAGGS-EB2 were infected with $M V_{E d m}$ at a MOI of 1 . Since no infectious virus could be detected at $24 \mathrm{~h}$ p.i., the amount of virus particles released from the cells was determined at $42 \mathrm{~h}$ p.i. by plaque assay. In contrast to $\mathrm{NiV}, \mathrm{MV}_{\mathrm{Edm}}$ virus titers in the supernatant of mock- and EB2-transfected Vero cells were similar (Fig. 4E) demonstrating that $\mathrm{MV}_{\mathrm{Edm}}$ infection was not affected by variations in EB2 expression. We also analyzed $\mathrm{MV}_{\mathrm{Edm}}$ replication in the presence of increased levels of its own receptor CD46, but we did not observe any negative influence of CD46 overexpression on productive $\mathrm{MV}_{\mathrm{Edm}}$ infection (data not shown). We thus conclude that the negative effect of EB2 overexpression on productive virus replication is specific for NiV.

\section{Cytoplasmic-tail truncated EB2 also interferes with NiV-} mediated cell-to-cell fusion and productive infection Clustering of EB2 by NiV G protein binding during virus entry may be an essential component of these processes and might trigger EB2 signaling. Supporting this idea, it was recently shown that the critical residues in EB2 involved in interaction with $\mathrm{NiV} \mathrm{G}$ are the same required 

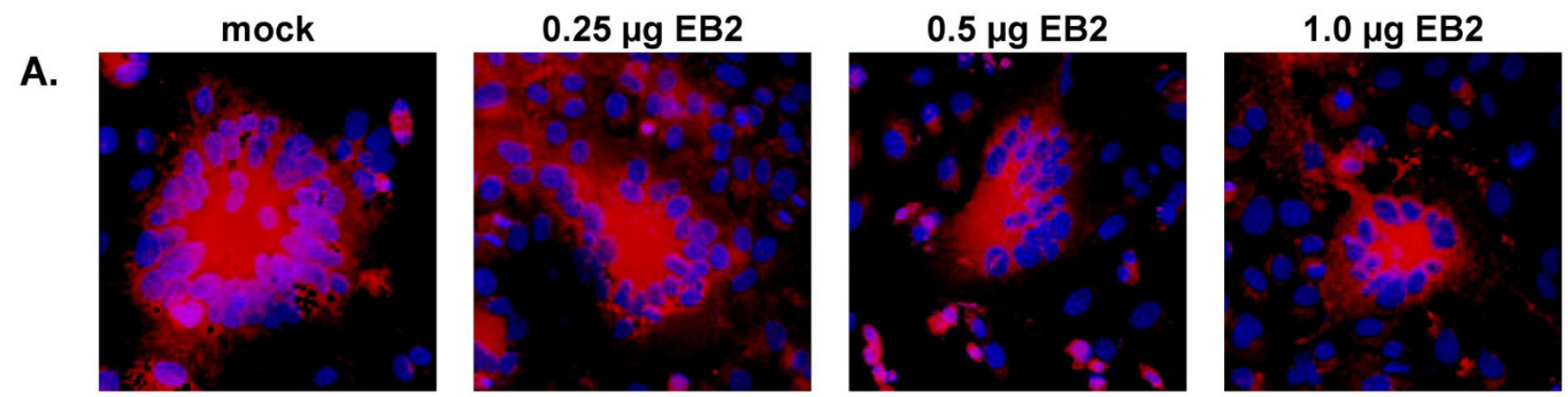

B.

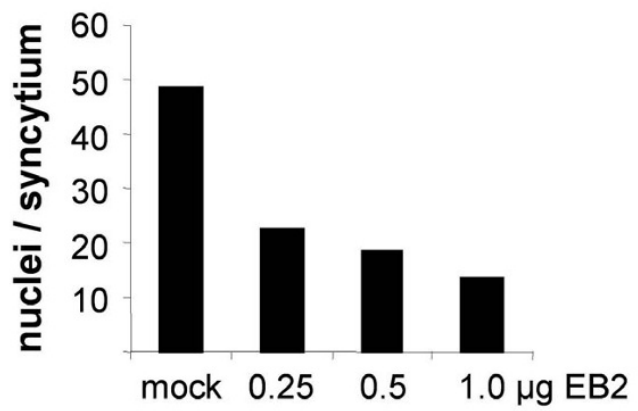

D.

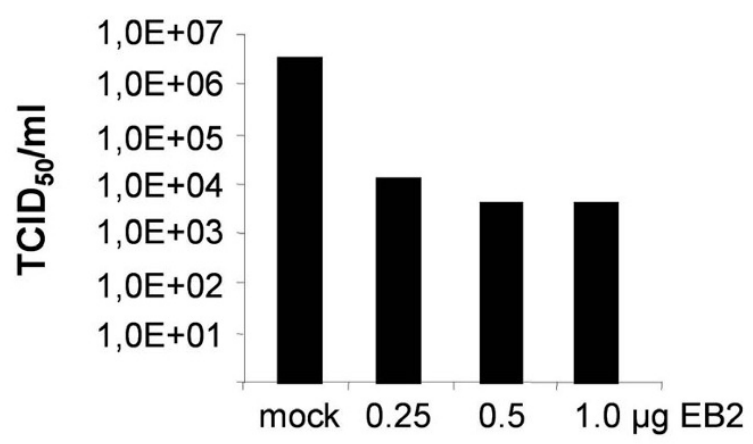

C.

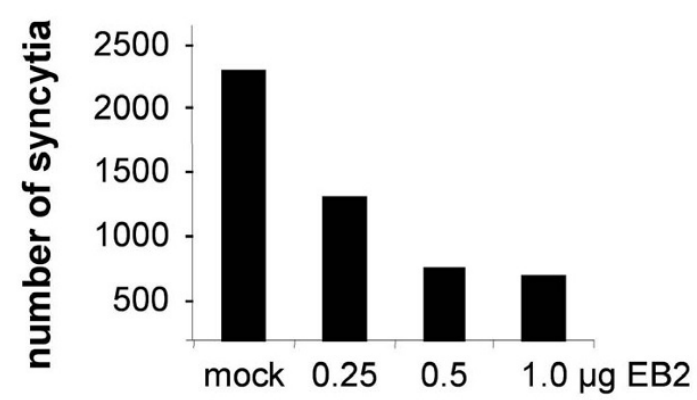

E.

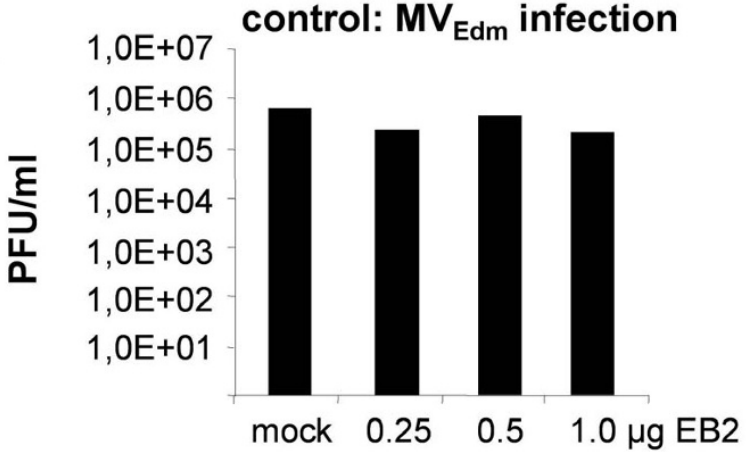

Figure 4

Influence of EB2 overexpression on $\mathrm{NiV}$ and control $\mathbf{M V}_{\mathrm{Edm}}$ infection. (A) Vero cells transfected with the indicated amounts of pCAGGS-EB2 were infected with NiV at a MOI of I at I $5 \mathrm{~h}$ after transfection. At $24 \mathrm{~h}$ p.i., cells were fixed and an immunostaining was performed using a NiV-specific guinea pig antiserum and rhodamine-conjugated secondary antibodies. Nuclei were visualized by DAPI staining. (B) Nuclei per syncytium were quantified as described in the legend to Fig. ID. (C) To determine the amount of initially NiV-infected cells, the total number of NiV-positive syncytia on each coverslip was counted. (D) Virus titers in the supernatant were determined by the $\mathrm{TCID}_{50}$ method at $24 \mathrm{~h}$ p.i.. (E) Vero cells transfected with different quantities of PCAGGS-EB2 were infected with $\mathrm{MV}_{\mathrm{Edm}}$ at a $\mathrm{MOI}$ of I. Virus titers in the supernatant were determined by plaque assay at $42 \mathrm{~h}$ p.i..

for interaction with the EphB2 receptor [27]. After NiV Ginduced EB2 clustering, NiV entry might be influenced by proteins interacting with the catalytic domain of the EB2 cytoplasmic tail, such as proteins containing PDZ domains which can stabilize high-ordered clustering into oligomeric arrays [45]. The density of this clustering or effects of EB2 signaling on actin cytoskeleton rearrangements may modulate the efficiency of virus-cell fusion.
Therefore, the negative effect of EB2 overexpression on $\mathrm{NiV}$ entry could be the result of an overshooting EB2 signaling. To evaluate this idea, we decided to study the influence of a tail-truncated $\triangle \mathrm{cEB} 2$ that lacks the C-terminal 67 amino acids on NiV replication [46] (Fig. 5A). First, we analyzed the effect of increased $\triangle \mathrm{cEB} 2$ surface expression on NiV glycoprotein-mediated cell-to-cell fusion in Vero cells by transfecting the NiV F and G genes in addi- 


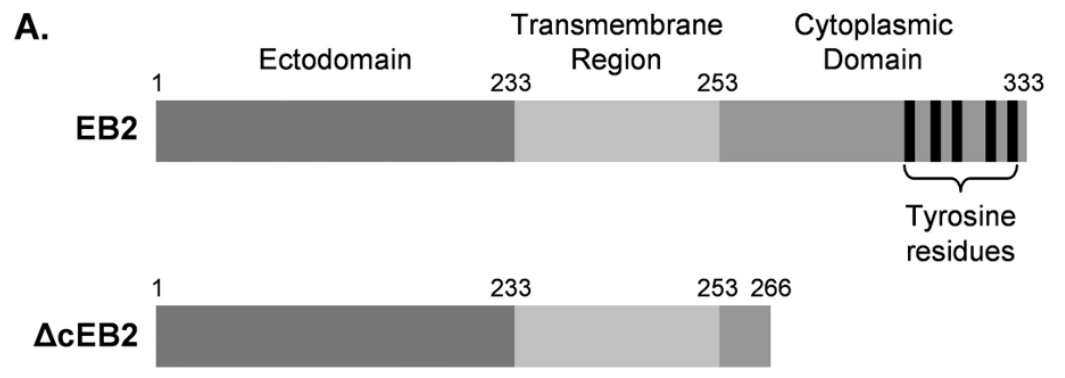

B.

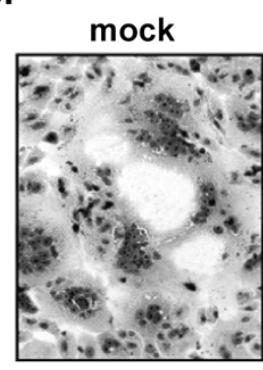
mock

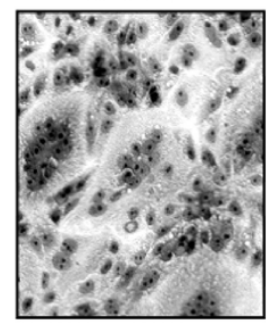

$0.25 \mu \mathrm{g}$ EB2

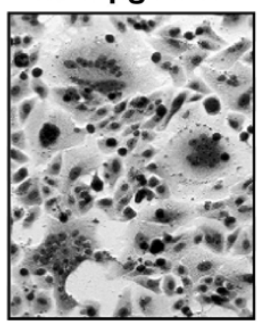

$0.25 \mu \mathrm{g} \triangle \mathrm{cEB} 2$

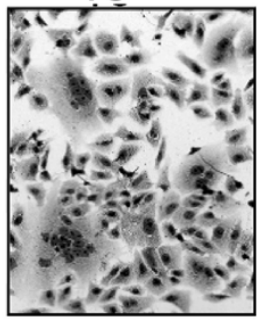

$0.5 \mu \mathrm{g}$ EB2

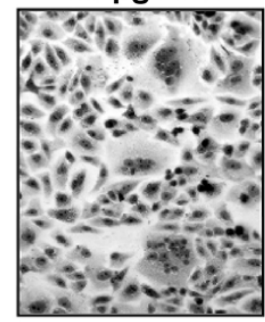

$0.5 \mu \mathrm{g} \Delta \mathrm{cEB} 2$

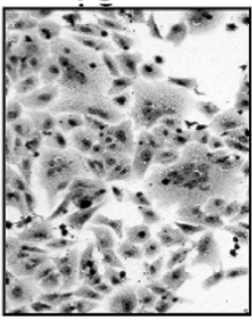

$1.0 \mu \mathrm{g} \mathrm{EB2}$

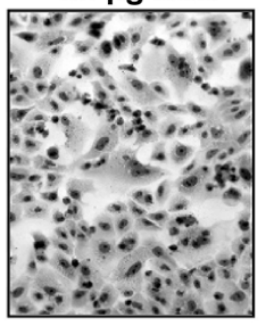

$1.0 \mu \mathrm{g} \Delta \mathrm{cEB} 2$

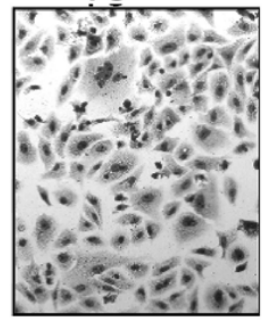

C.
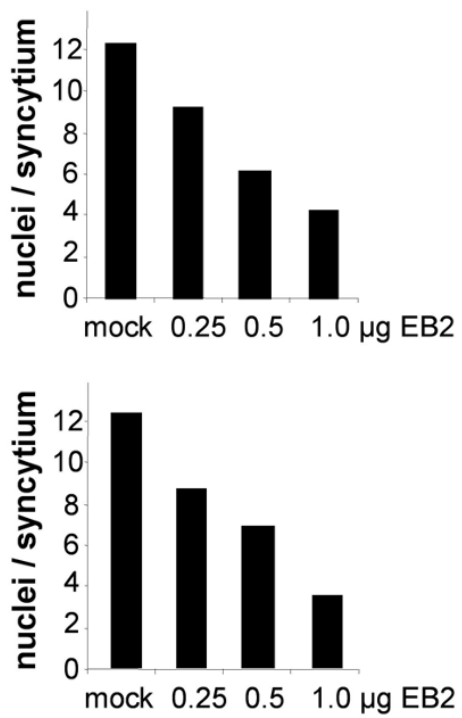

Figure 5

Influence of EB2 and $\triangle$ CEB2 overexpression on NiV glycoprotein-mediated cell-to-cell fusion. (A) Schematic diagram of EB2 and $\triangle \mathrm{cEB} 2$. Numbers indicate the amino acid positions. (B) Vero cells were cotransfected with constant amounts of NiV glycoprotein DNA and the indicated quantities of plasmids encoding either EB2 or $\Delta c E B 2$ protein. After $24 \mathrm{~h}, \mathrm{cells}$ were fixed and stained with Giemsa solution. (C) Quantification of syncytium formation was performed as described in the legend to Fig. ID.

tion to different amounts of EB2 or $\Delta \mathrm{cEB} 2$ plasmid DNA. As with wildtype EB2, an expression level-dependent reduction of the size of syncytia was observed in $\Delta \mathrm{cEB} 2-$ expressing cells (Fig. 5B and 5C). To investigate the effect of increased amounts of tail-truncated EB2 on NiV infection, $\Delta$ cEB2-transfected Vero cells were infected with $\mathrm{NiV}$ and syncytium formation and virus production was monitored at different time points p.i.. The quantitative analysis at $15 \mathrm{~h} \mathrm{p.i.} \mathrm{is} \mathrm{depicted} \mathrm{in} \mathrm{Fig.} 6$ and shows that overexpression of tail-truncated EB2 affected productive $\mathrm{NiV}$ infection to similar extents as full-length EB2 (Fig. 4). Transfection of only $0.25 \mu \mathrm{g}$ of $\Delta \mathrm{cEB} 2$ plasmid DNA already drastically interfered with $\mathrm{NiV}$-induced cell-to-cell spread (Fig. 6B) and reduced the release of infectious viruses by 2 to 3 log steps (Fig. 6C). Higher DNA concentrations had no further substantial effects. This indicates that receptor overexpression can downregulate productive $\mathrm{NiV}$ infection by interfering with virus entry and F- and Gmediated cell-to-cell fusion but cannot completely prevent infection.

\section{Cytoplasmic-tail truncated EB2 can function as NiV entry receptor}

The finding that overexpression of $\Delta \mathrm{cEB} 2$ interfered with $\mathrm{NiV}$ infection suggests that tail-truncated EB2 can also function as NiV binding partner. To directly test if $\Delta c E B 2$ can be used as $\mathrm{NiV}$ entry receptor or if it even provides a more effective receptor than full-length EB2 because it no 
A.

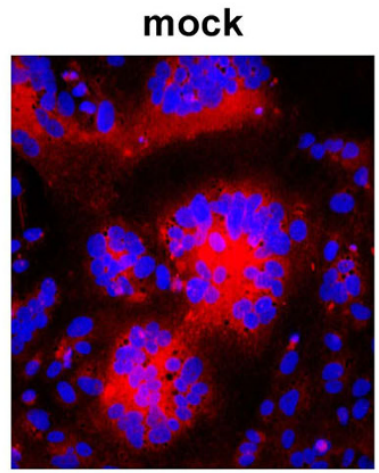

$0.25 \mu \mathrm{g} \Delta \mathrm{cEB} 2$

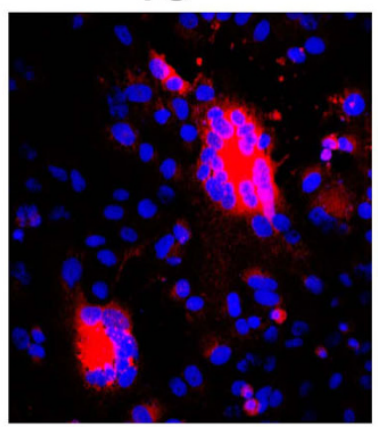

$0.5 \mu \mathrm{g} \Delta \mathrm{cEB} 2$

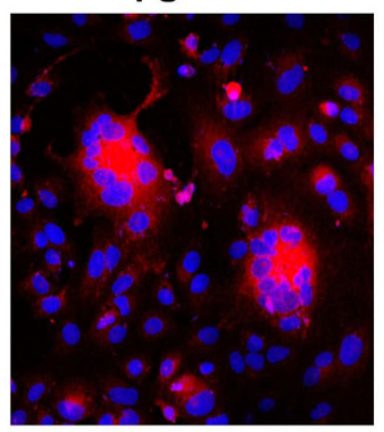

$1.0 \mu \mathrm{g} \Delta \mathrm{cEB} 2$

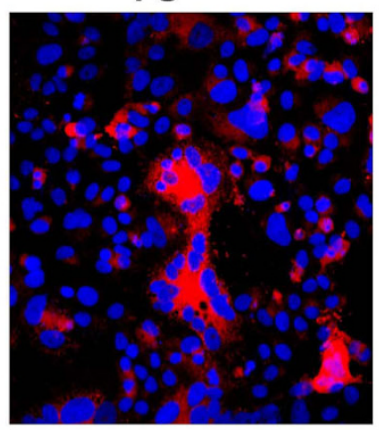

B.

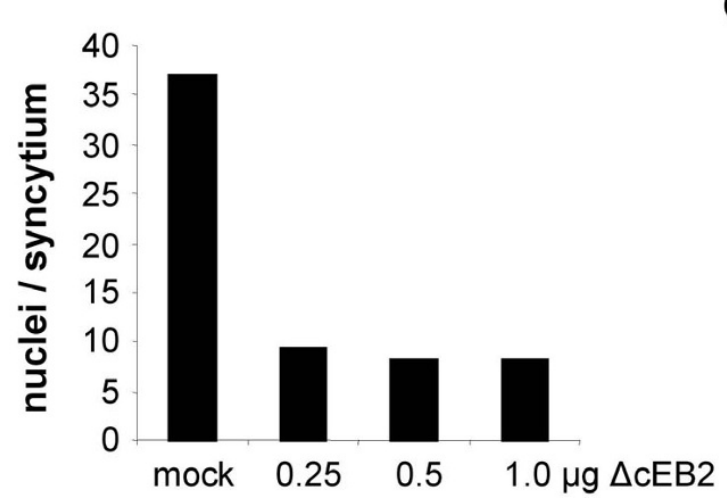

C.

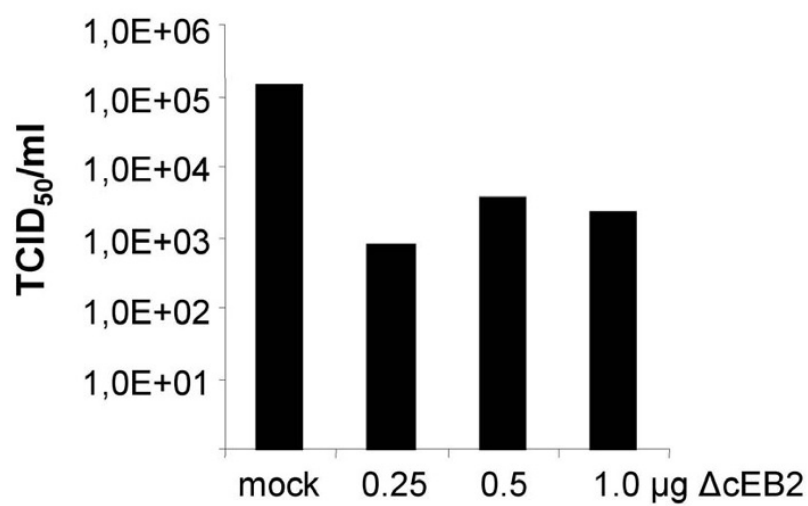

Figure 6

Influence of increased $\triangle \mathrm{CEB} 2$ expression levels on $\mathrm{NiV}$ infection. At $24 \mathrm{~h}$ p.t., Vero cells transfected with the indicated amounts of PCAGGS- $\triangle$ cEB2 were infected with $\mathrm{NiV}$ at a MOI of I. (A) At I5 h p.i., NiV-positive cells were stained as described in the legend to Fig. 4A. (B) Quantification of cell-to-cell fusion was carried out as described in the legend to Fig. ID. (C) Cell free virus was determined by the $\mathrm{TCID}_{50}$ method.

longer functions in signaling, we analyzed NiV infection in HeLa cells and porcine aortic endothelial cells (PAEC) stably expressing either wildtype or a tail-truncated $\triangle \mathrm{cEB} 2$. As we got similar results for both cell lines, only the results obtained for the PAEC, a well-studied cell line in terms of EB2 functions [46] are shown. To control the protein expression, EB2 and $\triangle \mathrm{CEB} 2$ proteins were immunoprecipitated from cell lysates and subjected to western blot analysis using an EB2-specific antibody. As shown in Fig. 7A, expression of EB2 and $\triangle \mathrm{CEB} 2$ in stably transfected PAEC is comparable. To characterize surface localization of EB2 and the tail-truncated variant, double-labeling experiments for EB2 and VE-cadherin, a marker protein for adherens junctions in endothelial cells, were performed. PAEC-EB2 and - $\triangle$ CEB2 were seeded on porous filter membranes and cultured for 7 days to form a polarized endothelial cell monolayer. Surface-expressed EB2 and $\triangle \mathrm{CEB} 2$ was detected by incubation with EphB4/Fc on ice and subsequent treatment with rhodamine-conjugated anti-human IgG antibodies. Then, cells were permeabilized and stained with a VE-cadherin antibody and a FITC- conjugated secondary antibody. Analysis of vertical sections through the endothelial cell monolayers identified an equal luminal expression of both EB2 and $\triangle \mathrm{cEB} 2$ (Fig. $7 \mathrm{~B})$. To control the loss of function of the tail-truncated EB2, an EphB4 receptor body uptake experiment was performed [33]. For this, PAEC-EB2 and PAEC- $\triangle \mathrm{CEB} 2$ were incubated with recombinant EphB4/Fc for $1 \mathrm{~h}$ at $37^{\circ} \mathrm{C}$ to allow binding of EphB4/Fc and co-endocytosis of EB2 and EphB4/Fc to occur. Surface-remained EphB4/Fc was visualized by incubation with rhodamine-conjugated secondary antibodies at $4{ }^{\circ} \mathrm{C}$. After fixation and permeabilization, intracellular EphB4/Fc was stained with FITC-conjugated secondary antibodies. In PAEC stably expressing wildtype EB2, numerous fluorescent intracellular vesicles (green dots) were found (Fig. 7C, PAEC-EB2). In contrast, in PAEC- $\Delta$ cEB2 expressing cells, no intracellular complexes were detected demonstrating that tail-truncated EB2 is no longer endocytosed. To analyze the receptor function of tail-truncated EB2, PAEC-EB2 or PAEC- $\Delta$ CEB2 were infected with $\mathrm{NiV}$ at a MOI of 1 . To monitor the infection at $24 \mathrm{~h}$ p.i., NiV-positive cells and 


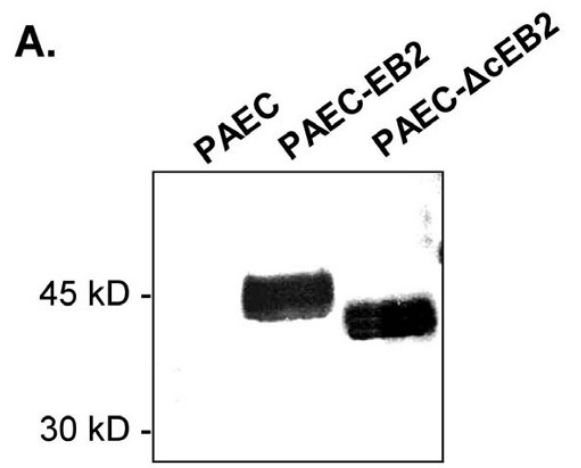

C.
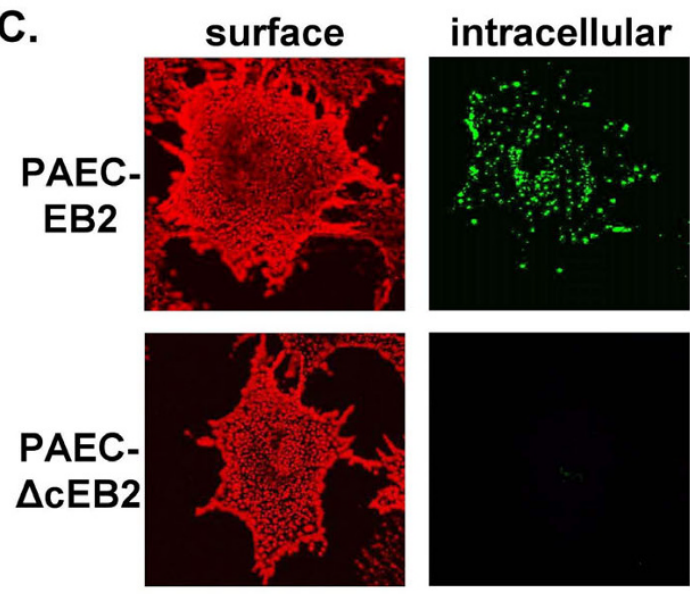

intracellular

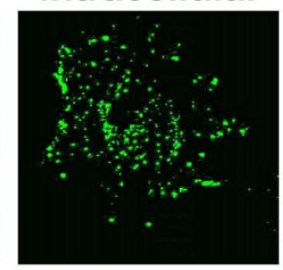

B.
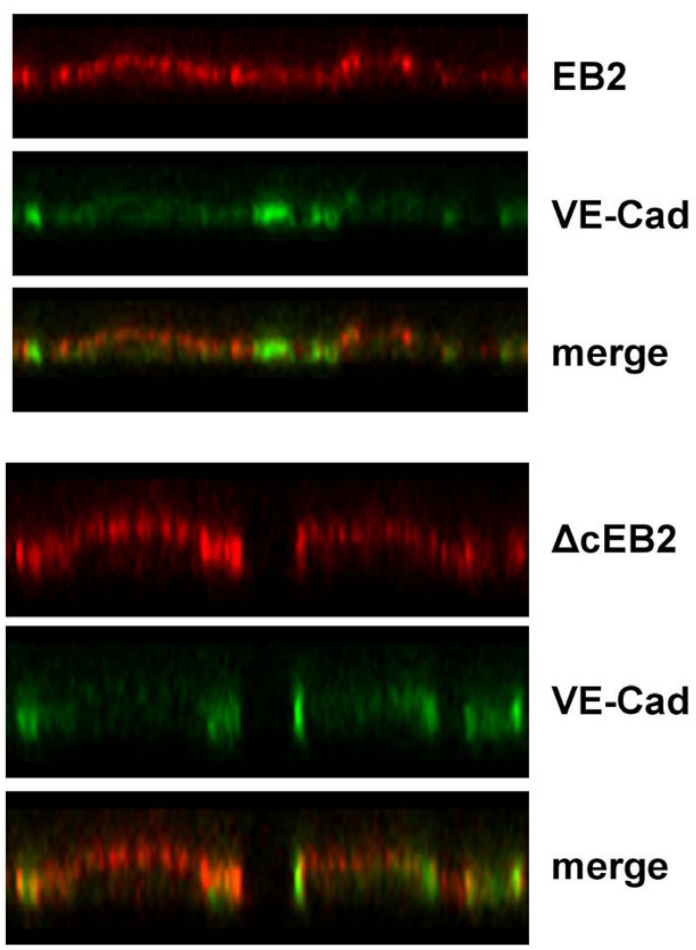

$\triangle \mathrm{cEB} 2$

VE-Cad

merge

D.

PAEC

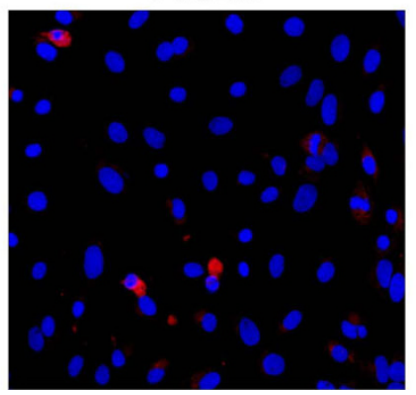

PAEC-EB2

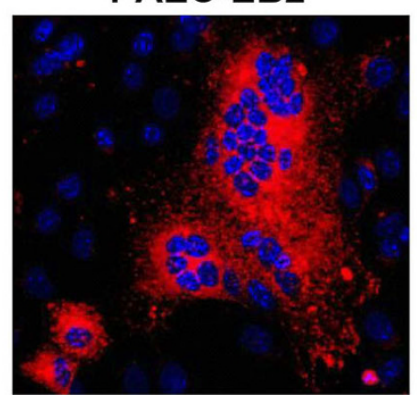

PAEC- $\triangle \mathrm{cEB} 2$

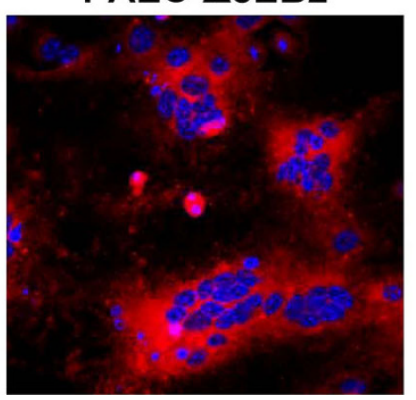

Figure 7

Characterization and NiV infection of EB2- and $\triangle$ cEB2-expressing PAEC. (A) EB2 and $\triangle$ cEB2 were immunoprecipitated from PAEC-EB2 and - $\triangle \mathrm{CEB} 2$ cell lysates, separated on a SDS gel and analyzed by Western blot analysis using an EB2-specific antibody. (B) Stably EB2- and $\triangle \mathrm{cEB} 2$-expressing PAEC were seeded on permeable filter supports. After 7 days, apical and basolateral surfaces were stained with EphB4/Fc and rhodamine-conjugated secondary antibodies. After fixation and permeabilization, cells were incubated with anti-VE-cadherin antibodies (VE-Cad) and FITC-conjugated secondary antibodies. (C) PAECEB2 and $-\triangle \mathrm{cEB} 2$ were incubated with recombinant EphB4/Fc for $\mathrm{I} \mathrm{h}$ at $37^{\circ} \mathrm{C}$ to allow binding and endocytosis to occur. Surface-remained EphB4/Fc was detected with rhodamine-conjugated secondary antibodies (surface) and internalized EphB4/Fc was stained after fixation and permeabilization by FITC-conjugated secondary antibodies (intracellular). (D) EB2- or $\Delta \mathrm{cEB} 2-$ expressing PAEC were infected with $\mathrm{NiV}$ at a $\mathrm{MOI}$ of $\mathrm{I}$. At $24 \mathrm{~h}$ p.i., immunostaining was performed as described in the legend to Fig. 4A. 
syncytia were detected by immunostaining and virus titers in the supernatant were quantified by the TCID $_{50}$ method. As shown in Fig. 7D, extensive cell-to-cell fusion could be detected in both PAEC-EB2 and PAEC- $\triangle \mathrm{cEB} 2$. The average size as well as the number of syncytia was similar. Accordingly, the amount of infectious virus particles released into the supernatant was the same $\left(3.1 \times 10^{6}\right.$ $\mathrm{TCID}_{50} / \mathrm{ml}$ for both cell lines). The finding that there are no substantial differences in the amount of initially infected cells, NiV-mediated cell-to-cell fusion and virus titers demonstrates that the tail-truncated $\triangle \mathrm{cEB} 2$ can fully function as NiV entry receptor in endothelial cells, the predominant target cells of the NiV infection in vivo.

\section{Discussion}

The major and new finding of this study is that productive $\mathrm{NiV}$ replication is counteracted by overexpression of the main NiV receptor EB2. By transfection of different amounts of EB2 gene into EB2-negative HeLa or EB2-positive Vero cells and quantification of syncytia formation upon coexpression of the two NiV envelope glycoproteins and in NiV-infected cells, we found that increasing amounts of EB2 plasmid DNA augmented the total number of cells expressing high levels of EB2 on the surface without changing the maximal EB2 surface density. Unexpectedly, EB2 expression higher than a very low threshold in HeLa cells or any additional EB2 expression in Vero cells resulted in a decreased cell-to-cell fusion, and also interfered with efficient virus entry. This negative effect on syncytia formation is mostly due to the fact that the expression levels of the NiV glycoproteins on the cell surface were reduced. However glycoprotein downregulation cannot be the reason for the reduced virus entry. To assess if the negative effect of elevated EB2 expression levels on virus entry and cell-to-cell fusion is linked to direct or indirect effects of an increased EB2 signaling, a cytoplasmic tail truncated and therefore signaling-defective EB2 ( $\triangle \mathrm{cEB} 2)$ was expressed in Vero cells. Interestingly, overexpression of $\Delta \mathrm{cEB} 2$ had a similar negative effect on virus entry and fusion, clearly showing that the detrimental influence of elevated receptor expression on NiV infection is not linked to EB2 signaling. NiV infection of endothelial cells expressing either full-length or truncated EB2 was similar in terms of virus entry and replication finally confirming that the receptor function of EB2 is independent of its cytoplasmic tail.

For their multiple physiological functions in angiogenesis, axon guidance, cell migration and neovascularization of tumors $[47,48]$, ephrins and Eph receptors must cluster to trigger bi-directional signaling into the ephrinexpressing cell (reverse signaling) and the contacting Eph receptor expressing cell (forward signaling) [49]. EB2mediated reverse signaling is known to depend on a catalytic domain comprising the conserved last 33 residues of the cytoplasmic domain which contains a PDZ domain binding motif and five conserved tyrosine residues $[30,50,51]$. One of the two known signaling pathways activated by $\mathrm{B}$ ephrins depends on the phosphorylation of the tyrosine residues and subsequent binding of Srchomology-2-domain-containing adaptor molecules like Grb4 initiating a cascade of signaling events that regulate cytoskeleton dynamics [52]. The second signaling pathway depends on the interaction with PDZ domain binding proteins like Grip1, Grip2, syntenin, Par3, PICK1 or Dvl2 inducing cluster formation, or binding partners with PDZ domains linked to a functional unit, for instance PTP-BL, Tiam1 or PDZ-RGS3 regulating G protein-coupled signaling events, finally resulting in guided cell migration $[25,30,53]$. In a previous report, the interesting idea was proposed that proteins containing a PDZ domain or other proteins which can interact with the EB2 cytoplasmic tail, may influence NiV entry into host cells and therefore could be a potential target for therapeutic treatments [54]. This concept that putative signals sent through EB2 upon interaction with NiV G may be an essential component of the entry process was mainly based on the finding that the NiV-G protein is a tetramer as it is also proposed for Eph receptors $[28,55,56]$. Thus, $\mathrm{G}$ binding might lead to EB2 clustering and activation of the signaling cascade. However, the data presented in this paper indicate that cellular binding partners of the EB2 catalytic domain are not involved in NiV entry, because a tail-truncated EB2 fully functions as host cell receptor and downregulates NiV infection when it is overexpressed. But even if EB2-mediated signaling per se is obviously not involved in virus entry and spread via cell-to-cell fusion, it remains to be determined if $\mathrm{NiV}$ binding to its receptor triggers EB2-mediated signaling possibly affecting host cell functions or apoptosis, as it is described for HIV $[57,58]$.

It is well known that expression levels of viral entry receptors can be crucial for virus infection. For instance, adenovirus binding to the coxsackievirus-adenovirus receptor (CAR) and subsequent infection clearly decreased if CAR expression is reduced after cytokine treatment [42]. Similarly, the density of cell surface-expressed CD81 was shown to be a key determinant for productive hepatitis $\mathrm{C}$ virus (HCV) entry into host cells. Cell susceptibility to HCV infection could be increased by augmenting CD81 surface densities up to a certain threshold, further increase did not have any additional positive or negative effects [37]. In the case of the human immunodeficiency virus (HIV) cell surface concentrations of receptors and coreceptors also control infection efficiency. Concentrations of CD4 and CCR5 required for efficient infections by HIV were found to be interdependent, requirements for each were increased when the other component was limited [40]. For several other retroviruses positive correlations of 
receptor overexpression and virus infection were also reported $[36,38,39,41,43]$. In all reports so far, upregulation of receptor densities had either no or beneficial effects on virus replication. A negative effect of increased virus receptor expression on virus entry and productive infection as demonstrated in this study has never been reported, and thus might reflect a unique characteristic of the highly virulent $\mathrm{NiV}$.

Coexpression of virus receptors and viral receptor binding glycoproteins in one cell can result in complex formation and retention of both proteins in intracellular compartments leading to downregulation of the receptor on the cell surface. This phenomenon of receptor interference is described for several viral proteins which are known to interact with or even induce degradation of their cellular receptors [59-65]. Even though Sawatsky et al. [66] described EB2 surface expression to be unchanged after coexpression of NiV G, our finding that the NiV glycoprotein surface expression levels are downregulated in EB2 expressing cells indicates an intracellular interaction and subsequent retention of the two proteins. However, this effect that leads to reduced cell-to-cell fusion efficiency does not explain the less efficient virus entry into Vero cells expressing additional EB2. Reduced infection of these cultures is most likely due to an imbalance between cellular receptors and viral receptor binding proteins in the virus envelope. Since fusion and the lateral mobility of paramyxoviral glycoproteins in the target cell membrane correlate [67], NiV G interactions with too many receptor molecules on a host cell likely hinders the virus-cell fusion process by interfering with the optimal formation or mobility of fusion pore complexes required for virus-cell fusion and subsequent virus entry. Our observation that cell-to-cell fusion is decreased if cells expressing the $\mathrm{NiV}$ glycoproteins were mixed with cells expressing increased amounts of EB2 supports the model that the balance between the amount of fusogenic glycoproteins on one membrane and the density of receptors on adjacent membranes critically determines fusion efficiency (Thiel, unpublished observations). Given that more cells in a culture express too high EB2 concentrations, more viral NiV $\mathrm{G}$ proteins are clustered with receptors. This prevents or slows down the fusion process required for virus entry or cell-to-cell fusion.

Since high viral replication in the central nervous system is likely an important factor for the high mortality rates of NiV infection in humans [14], EB2 expression levels may critically influence viral replication by regulating virus entry, virus spread by cell-to-cell fusion and particle release. Thus, fatal or nonfatal outcome of a NiV encephalitis might depend on EB2 expression levels. The histopathological finding that in brain tissues of NiVinfected patients, syncytial cells were only found in $27 \%$ of the cases whereas vasculitis, thrombosis and necrosis were seen in over $80 \%$ [13] might reflect differences in the EB2 expression levels resulting in different extents of NiVmediated cell-to-cell fusion. Besides its possible influence on the outcome of the acute infection, differences in EB2 expression levels might also contribute to the relapse encephalitis which was found in some patients at 13-39 days after mild or asymptomatic acute NiV infection [12]. As it is well known, that EB2 expression in vivo is regulated by the local microenvironment within the vascular tree [33], and up-regulation of EB2 is controlled by the Notch pathway as well as by hemodynamic factors or vascular endothelial growth factor (VEGF) [33,68-70], NiV infection of brain endothelia might induce changes in the local microenvironment thereby inducing up- or downregulation of EB2 and influencing further virus spread. Using a suitable animal model $[7,71,72]$, it remains to be elucidated if up- or downregulation of the $\mathrm{NiV}$ receptor is able to influence NiV spread in vivo and thus might be a potential therapeutic option for treatment of NiV encephalitis in early stages of infection.

\section{Conclusion}

In summary, this paper demonstrates for the first time that overexpression of a virus receptor substantially interferes with virus infection on the level of virus entry and cell-to-cell spread by two independent pathways. Whereas cell-to-cell fusion is mainly reduced as a consequence of $\mathrm{NiV}$ glycoprotein downregulation from the cell surface, virus entry is rather impaired by disturbing the optimal balance between the amount of fusogenic glycoproteins in the virus envelope and receptors on the host cell surface.

\section{Methods \\ Cell cultures}

Vero (African green monkey kidney) and HeLa (human cervical cancer) cells were maintained in Dulbecco's modified minimal essential medium (DMEM, Gibco) containing $10 \%$ fetal calf serum (FCS), $4 \mathrm{mM} \mathrm{L-glutamine,} 100$ units $/ \mathrm{ml}$ penicillin and $0.1 \mathrm{mg} / \mathrm{ml}$ streptomycin. PAE (porcine aortic endothelial) cells were cultured in DMEM/ F12 + GLUTAMAX (Gibco) supplemented with 10\% FCS, penicillin and streptomycin.

\section{Virus infections}

The NiV strain used in this study was isolated from human brain tissue (kindly provided by J. Cardosa) and propagated as described earlier [73]. For NiV infection, confluent cell monolayers of different cell lines were infected at a multiplicity of infection (MOI) of 1 . After incubation for $1 \mathrm{~h}$ at $37^{\circ} \mathrm{C}$, inocula were removed, cells were washed twice and then cultured with medium containing $2 \%$ FCS at $37^{\circ} \mathrm{C}$. All work with live $\mathrm{NiV}$ was performed under BSL4 conditions. 
Measles virus vaccine strain Edmonston $\left(\mathrm{MV}_{\mathrm{Edm}}\right)$ was grown and propagated on Vero cells as described previously [74]. For $M V_{E d m}$ infection studies, cells were infected with $M V_{E d m}$ at a MOI of 1 . After incubation for $2 \mathrm{~h}$ at $37^{\circ} \mathrm{C}$, virus was removed by extensive washings and cells were incubated with medium containing $2 \% \mathrm{FCS}$ at $33^{\circ} \mathrm{C}$.

\section{Plasmids and transfections}

The NiV F and G glycoprotein open reading frames (GenBank $^{\mathrm{TM}}$ accession number AF212302) were subcloned into the pczCFG5 expression vector as described by Moll et al. [75]. Cloning of the $\mathrm{MV}_{\mathrm{Edm}}$ glycoprotein genes ( $\mathrm{F}$ and $\mathrm{H}$ ) into the PCG expression vector has been described earlier [76]. The human EB2 gene and a C-terminally truncated EB2 version (encoding amino acid residues $1-266$ ), designated as $\triangle \mathrm{CEB} 2$ [46], were subcloned into the NotI site and SacI site of a pCAGGS expression vector [77]. Human CD46 gene was cloned into the pHßAPr.1-neo expression vector as specified previously [78].

Transfections of Vero and HeLa cells were performed by using the cationic liposome based transfection reagent Lipofectamine 2000 (Invitrogen) according to the supplier's instructions. Stably EB2- and $\Delta$ CEB2-expressing PAE cells were constructed as described by Füller $e t$ al. [46].

\section{EB2 surface staining}

HeLa cells transiently expressing varying amounts of EB2 were cultured on coverslips. At $24 \mathrm{~h}$ post transfection (p.t.), recombinant mouse EphB4/Fc, a soluble EB2 receptor fused to the Fc region of human IgG (R\&D Systems) was added at a concentration of $2 \mu \mathrm{g} / \mathrm{ml}$ for $1 \mathrm{~h}$ at $4^{\circ} \mathrm{C}$. Bound EphB4/Fc was stained with rhodamine-conjugated anti-human IgG antibodies on ice (dilution 1:200; Jackson ImmunoResearch). Nuclei were visualized by 4',6diamidino-2-phenylindole (DAPI) staining. Representative merged images of the DAPI and rhodamine channels were recorded with a Zeiss Axiovert $200 \mathrm{M}$ microscope.

Stably EB2- and $\triangle \mathrm{CEB} 2$-expressing PAE cells were cultured on 0,4 $\mu \mathrm{m}$-pore size ThinCert polyethylenterephthalat filter supports (Greiner Bio-one). After 7 days, the apical and basolateral surfaces were incubated with recombinant EphB4/Fc $\left(2 \mu \mathrm{g} / \mathrm{ml} ; 2 \mathrm{~h}\right.$ at $\left.4{ }^{\circ} \mathrm{C}\right)$ and rhodamine-conjugated secondary antibodies (dilution 1:200; $2 \mathrm{~h}$ at $4^{\circ} \mathrm{C}$ ). To visualize the adherens junctions, cells were fixed with $4 \%$ paraformaldehyde (PFA), permeabilized with $0.1 \%$ Triton X-100 for 15 min and subsequently treated with anti VE-cadherin antibodies (Santa Cruz) at a dilution of 1:100 for $2 \mathrm{~h}$ at $4{ }^{\circ} \mathrm{C}$ and fluorescein isothiocyanate (FITC)-conjugated anti-mouse IgG antibodies (dilution 1:200; $2 \mathrm{~h}$ at $4^{\circ} \mathrm{C}$; Jackson ImmunoResearch). Filter membranes were analyzed with a confocal laser scanning microscope (LSM 510, Zeiss).

\section{Flow cytometry}

HeLa or Vero cells were transfected with different amounts of EB2 DNA. At 24 h p.t., cells were detached with phosphate buffered saline (PBS) containing $5 \mathrm{mM}$ EDTA, washed twice and $5 \times 10^{5}$ cells were subsequently incubated with an EB2-specific antibody (dilution 1:10; R\&D Systems) for $45 \mathrm{~min}$ at $4^{\circ} \mathrm{C}$. Primary antibodies were detected by FITC-conjugated anti-goat IgG secondary antibodies (dilution 1:100; Jackson ImmunoResearch) and flow-cytometric analyses were carried out with a FACScan (Guava Technologies). Since it has been shown that coexpression of $\mathrm{NiV} \mathrm{G}$ protein did not influence the expression of EB2 on the cell surface [66], FACS analysis was performed in cells expressing EB2 only.

\section{Fusion assays}

As it has been reported for the closely related $\mathrm{HeV}$ glycoproteins that the ratio of $F$ to $G$ plasmids transfected into cells can influence the efficiency of membrane fusion [79], we first tested the capacity of varying levels of pczCFG5-F and pczCFG5-G transfected into Vero cells to mediate cell-to-cell fusion. In agreement with what has been shown for the $\mathrm{HeV}$ glycoproteins, increased fusion was observed with greater amounts of the $G$ protein plasmid. Since NiV glycoprotein-mediated syncytia formation was found to be maximal at a 1:5 ratio of $\mathrm{NiV} F$ to $\mathrm{NiV} G$ plasmid DNA, cells were cotransfected with constant amounts of plasmids encoding either the NiV glycoproteins $\mathrm{F}$ and $\mathrm{G}$ at this ratio or the $\mathrm{MV}$ glycoproteins $\mathrm{F}$ and $\mathrm{H}$ (optimal ratio of 1:1), in addition to varying amounts of pCAGGS-EB2, pCAGGS- $\triangle$ cEB2 or pHßAPr.1-neo-CD46, respectively. At $24 \mathrm{~h}(\mathrm{NiV})$ or $15 \mathrm{~h}(\mathrm{MV})$ p.t., cells were fixed with ethanol for $10 \mathrm{~min}$ and incubated with a 1:10 diluted Giemsa staining solution for $30 \mathrm{~min}$ to visualize syncytium formation. Representative microscopic fields were photographed. To quantify the size of syncytia, the number of nuclei per syncytium of twenty randomly chosen syncytia were counted and averaged.

\section{Surface biotinylation}

Cell surface proteins were labeled with sulfosuccinimidobiotin (S-NHS-biotin; Pierce) and subsequently lysed in radioimmunoprecipitation assay buffer (RIPA) as described previously [17]. Immunoprecipitation of $\mathrm{NiV} \mathrm{F}$ from surface-biotinylated cells was carried out with an Fspecific antibody directed against amino acids 523 to 541 of the NiV F cytoplasmic domain (dilution 1:100; ImmunoGlobe Antikörpertechnik), and NiV G was immunoprecipitated with a polyclonal NiV-specific antiserum (dilution 1:350). MV glycoproteins were isolated using For H-specific monoclonal antibodies [76]. Immunoprecipitates were separated on a $12 \%$ polyacrylamide gel under reducing ( $\mathrm{NiV} \mathrm{G}, \mathrm{MV} \mathrm{F}$ and $\mathrm{H}$ ) or non-reducing conditions (NiV F) and blotted to nitrocellulose. Nonspecific binding sites were blocked with 5\% nonfat dry milk 
in PBS. To detect surface-biotinylated $\mathrm{NiV}$ and MV glycoproteins, blots were incubated with IRDye 800-conjugated streptavidin for $45 \mathrm{~min}$ at $4{ }^{\circ} \mathrm{C}$ (Rockland; dilution $1: 8000)$. Fluorescent signals were analyzed using a LiCorOdyssey infrared imaging system (LI-COR Biosciences $\mathrm{GmbH})$.

\section{NiV infection of cells expressing varying amounts of EB2 or $\triangle c E B 2$}

Vero cells grown on coverslips were transfected with varying amounts of pCAGGS-EB2 or $-\Delta$ cEB2. At 15 h p.t., infection with $\mathrm{NiV}$ was performed as described above. $\mathrm{NiV}$-positive cells or syncytia were detected by indirect immunofluorescence as described recently [15]. Briefly, after fixation with $4 \%$ PFA for $48 \mathrm{~h}$, cells were permeabilized with methanol-acetone and incubated with a NiVspecific guinea pig antiserum (dilution 1:1000) for $1 \mathrm{~h}$ at $4{ }^{\circ} \mathrm{C}$. Primary antibodies were detected with rhodamineconjugated anti-guinea pig IgG antibodies (Jackson ImmunoResearch; dilution 1:200; $45 \mathrm{~min}$ at $4^{\circ} \mathrm{C}$ ). Nuclei were counterstained by DAPI. Images were recorded using a Zeiss Axiovert $200 \mathrm{M}$ microscope.

The size of NiV-induced syncytia was quantified as described above. The number of initially infected cells in each sample was determined by counting the number of NiV-positive syncytia. To quantify virus release, virus titers in the supernatant were calculated by the $50 \%$ tissue culture infective dose $\left(\mathrm{TCID}_{50}\right)$ method on Vero cells [80].

\section{Immunoprecipitation and Western Blot analysis of EB2 and $\triangle \mathrm{CEB} 2$}

Stably EB2- and $\triangle \mathrm{cEB} 2-$-expressing PAEC were lysed in immunoprecipitation buffer (1\% Triton X-100, $0.15 \mathrm{M}$ $\mathrm{NaCl}, 1 \mathrm{mM}$ EDTA, $10 \mathrm{mM}$ Tris-HCl, pH 7,4). EB2- and $\Delta \mathrm{cEB} 2$ were immunoprecipitated with EphB4/Fc (dilution $1: 100)$ and $100 \mu \mathrm{l}$ of a suspension of protein A/G sepharose CL-4B (Pierce). After three washes, immunocomplexes were suspended in reducing sample buffer. Precipitates were subsequently separated on a $10 \%$ polyacrylamide gel and transferred to nitrocellulose. The blot was probed with $0,3 \mu \mathrm{g}$ anti-EB2 (R\&D Systems) followed by incubation with peroxidase-conjugated anti-goat IgG antibodies (dilution 1:4000; Jackson ImmunoResearch). EB2 and $\triangle \mathrm{cEB} 2$ proteins were visualized with the enhanced chemoluminescence system (SuperSignal ${ }^{\circledR}$ West Pico Chemoluminescent Substrate; Pierce) by exposure to an autoradiography film (GE Healthcare).

\section{Endocytosis of EB2 and $\triangle \mathrm{CEB2}$}

Stably EB2- and $\triangle \mathrm{cEB} 2$-expressing PAEC were seeded on coverslips and grown to subconfluency. Cells were then incubated with $2 \mu \mathrm{g} / \mathrm{ml}$ recombinant EphB4/Fc for $1 \mathrm{~h}$ at $37^{\circ} \mathrm{C}$ to allow binding and endocytosis to proceed. Surface-remained EphB4/Fc was stained with rhodamine- conjugated anti-human IgG antibodies (dilution 1:50) for $90 \mathrm{~min}$ at $4^{\circ} \mathrm{C}$. After fixation and permeabilization with methanol-acetone, internalized EphB4/Fc was detected by FITC-conjugated anti-human IgG antibodies (dilution 1:500, Jackson ImmunoResearch) for $35 \mathrm{~min}$ at $4^{\circ} \mathrm{C}$. Images of representative cells were recorded using a Zeiss Axiovert $200 \mathrm{M}$ microscope.

\section{Competing interests}

The authors declare that they have no competing interests.

\section{Authors' contributions}

LT and SE carried out most of the experiments and helped to draft the manuscript. SD performed all work under BSL- 4 conditions. AM designed the study. DP and HGA provided critical reagents. AM, DP and HA helped with the analysis and the interpretation of the data and drafted the manuscript. All authors read and approved the final manuscript.

\section{Acknowledgements}

We thank M. Czub, H. Weingartl, and H. Feldmann for supporting the BSL4 training of S.D. and for the anti-NiV guinea pig sera. This work was supported by the Deutsche Forschungsgemeinschaft to HGA (Au83/9-3 within the SPPI 190 "The tumor vessel interface") and to A.M. (GK 1216 "Intraand intercellular transport and communication" and TP BII within the SFB 593 "Mechanisms of cellular compartmentalization and the relevance for disease").

\section{References}

I. Chua KB, Goh KJ, Wong KT, Kamarulzaman A, Tan PS, Ksiazek TG, Zaki SR, Paul G, Lam SK, Tan CT: Fatal encephalitis due to Nipah virus among pig-farmers in Malaysia. Lancet 1999, 354(9186): 1257-1259.

2. Chua KB: Nipah virus outbreak in Malaysia. J Clin Virol 2003, 26(3):265-275.

3. Harcourt BH, Tamin A, Ksiazek TG, Rollin PE, Anderson L, Bellin W], Rota PA: Molecular characterization of Nipah virus, a newly emergent paramyxovirus. Virology 2000, 27 I(2):334-349.

4. Wang LF, Yu M, Hansson E, Pritchard LI, Shiell B, Michalski WP, Eaton BT: The exceptionally large genome of Hendra virus: support for creation of a new genus within the family Paramyxoviridae. J Virol 2000, 74(21):9972-9979.

5. Chua KB, Koh CL, Hooi PS, Wee KF, Khong JH, Chua BH, Chan YP, Lim ME, Lam SK: Isolation of Nipah virus from Malaysian Island flying-foxes. Microbes Infect 2002, 4(2): I45-I5I.

6. Hooper P, Zaki S, Daniels P, Middleton D: Comparative pathology of the diseases caused by Hendra and Nipah viruses. Microbes Infect 200I, 3(4):3I5-322.

7. Wong KT, Grosjean I, Brisson C, Blanquier B, Fevre-Montange M, Bernard A, Loth P, Georges-Courbot MC, Chevallier M, Akaoka H, et al.: A golden hamster model for human acute Nipah virus infection. Am J Pathol 2003, I63(5):2। 27-2। 37 .

8. Yob JM, Field H, Rashdi AM, Morrissy C, van der Heide B, Rota P, bin Adzhar A, White J, Daniels $P$, jamaluddin A, et al.: Nipah virus infection in bats (order Chiroptera) in peninsular Malaysia. Emerg Infect Dis 200I, 7(3):439-441.

9. Gurley ES, Montgomery JM, Hossain MJ, Bell M, Azad AK, Islam MR, Molla MA, Carroll DS, Ksiazek TG, Rota PA, et al.: Person-to-person transmission of Nipah virus in a Bangladeshi community. Emerg Infect Dis 2007, I 3(7): 103 I-I 037.

10. Hsu VP, Hossain MJ, Parashar UD, Ali MM, Ksiazek TG, Kuzmin I, Niezgoda M, Rupprecht C, Bresee J, Breiman RF: Nipah virus encephalitis reemergence, Bangladesh. Emerg Infect Dis 2004, I O( I 2):2082-2087. 
II. Luby SP, Rahman M, Hossain MJ, Blum LS, Husain MM, Gurley E, Khan R, Ahmed BN, Rahman S, Nahar N, et al.: Foodborne transmission of Nipah virus, Bangladesh. Emerg Infect Dis 2006, I 2(I 2): | 888-|894.

12. Goh KJ, Tan CT, Chew NK, Tan PS, Kamarulzaman A, Sarji SA, Wong KT, Abdullah BJ, Chua KB, Lam SK: Clinical features of Nipah virus encephalitis among pig farmers in Malaysia. N EnglJ Med 2000, 342(I7): 1229-1235.

13. Wong KT, Shieh W], Kumar S, Norain K, Abdullah W, Guarner J, Goldsmith CS, Chua KB, Lam SK, Tan CT, et al.: Nipah virus infection: pathology and pathogenesis of an emerging paramyxoviral zoonosis. Am J Pathol 2002, I6I(6):2153-2167.

14. Chua KB, Lam SK, Tan CT, Hooi PS, Goh KJ, Chew NK, Tan KS, Kamarulzaman A, Wong KT: High mortality in Nipah encephalitis is associated with presence of virus in cerebrospinal fluid. Ann Neurol 2000, 48(5):802-805.

15. Diederich S, Thiel L, Maisner A: Role of endocytosis and cathepsin-mediated activation in Nipah virus entry. Virology 2008.

16. Tamin A, Harcourt BH, Ksiazek TG, Rollin PE, Bellini WJ, Rota PA: Functional properties of the fusion and attachment glycoproteins of Nipah virus. Virology 2002, 296(I):190-200.

17. Diederich S, Moll M, Klenk HD, Maisner A: The nipah virus fusion protein is cleaved within the endosomal compartment. J Biol Chem 2005, 280(33):29899-29903.

18. Pager CT, Craft WW Jr, Patch J, Dutch RE: A mature and fusogenic form of the Nipah virus fusion protein requires proteolytic processing by cathepsin L. Virology 2006, 346(2):25I-257.

19. Vogt C, Eickmann M, Diederich S, Moll M, Maisner A: Endocytosis of the nipah virus glycoproteins. J Virol 2005, 79(6):3865-3872.

20. Bonaparte MI, Dimitrov AS, Bossart KN, Crameri G, Mungall BA Bishop KA, Choudhry V, Dimitrov DS, Wang LF, Eaton BT, et al:: Ephrin-B2 ligand is a functional receptor for Hendra virus and Nipah virus. Proc Natl Acad Sci USA 2005, I02(30): 10652-10657.

21. Negrete OA, Levroney EL, Aguilar HC, Bertolotti-Ciarlet A, Nazarian $\mathrm{R}$, Tajyar S, Lee B: EphrinB2 is the entry receptor for Nipah virus, an emergent deadly paramyxovirus. Nature 2005, 436(7049): $401-405$

22. Augustin HG, Reiss Y: EphB receptors and ephrinB ligands: regulators of vascular assembly and homeostasis. Cell Tissue Res 2003, 3 | 4(I):25-3I.

23. Gale NW, Baluk P, Pan L, Kwan M, Holash J, DeChiara TM, McDonald DM, Yancopoulos GD: Ephrin-B2 selectively marks arterial vessels and neovascularization sites in the adult, with expression in both endothelial and smooth-muscle cells. Dev Biol 200I, 230(2): $151-160$.

24. Palmer A, Zimmer M, Erdmann KS, Eulenburg V, Porthin A, Heumann $R$, Deutsch $U$, Klein R: EphrinB phosphorylation and reverse signaling: regulation by Src kinases and PTP-BL phosphatase. Mol Cell 2002, 9(4):725-737.

25. Poliakov A, Cotrina M, Wilkinson DG: Diverse roles of eph receptors and ephrins in the regulation of cell migration and tissue assembly. Dev Cell 2004, 7(4):465-480.

26. Shin D, Garcia-Cardena G, Hayashi S, Gerety S, Asahara T, Stavrakis G, Isner J, Folkman J, Gimbrone MA Jr, Anderson DJ: Expression of ephrinB2 identifies a stable genetic difference between arterial and venous vascular smooth muscle as well as endothelial cells, and marks subsets of microvessels at sites of adult neovascularization. Dev Biol 200I, 230(2): 139-150.

27. Negrete OA, Wolf MC, Aguilar HC, Enterlein S, Wang W, Muhlberger E, Su SV, Bertolotti-Ciarlet A, Flick R, Lee B: Two key residues in ephrinB3 are critical for its use as an alternative receptor for Nipah virus. PLoS Pathog 2006, 2(2):e7.

28. Negrete OA, Chu D, Aguilar HC, Lee B: Single amino acid changes in the Nipah and Hendra virus attachment glycoproteins distinguish ephrinB2 from ephrinB3 usage. J Virol 2007, 8 I(19): 10804-108|4.

29. Adams RH: Vascular patterning by Eph receptor tyrosine kinases and ephrins. Semin Cell Dev Biol 2002, I3(I):55-60.

30. Kullander K, Klein R: Mechanisms and functions of Eph and ephrin signalling. Nat Rev Mol Cell Biol 2002, 3(7):475-486.

31. Makinen T, Adams RH, Bailey J, Lu Q, Ziemiecki A, Alitalo K, Klein R, Wilkinson GA: PDZ interaction site in ephrinB2 is required for the remodeling of lymphatic vasculature. Genes Dev 2005, I 9(3):397-4I0.
32. Heroult M, Schaffner F, Augustin HG: Eph receptor and ephrin ligand-mediated interactions during angiogenesis and tumor progression. Exp Cell Res 2006, 3 I 2(5):642-650.

33. Korff T, Dandekar G, Pfaff D, Fuller T, Goettsch W, Morawietz H, Schaffner F, Augustin HG: Endothelial ephrinB2 is controlled by microenvironmental determinants and associates contextdependently with CD3I. Arterioscler Thromb Vasc Biol 2006, 26(3):468-474.

34. Adams RH, Diella F, Hennig S, Helmbacher F, Deutsch U, Klein R The cytoplasmic domain of the ligand ephrinB2 is required for vascular morphogenesis but not cranial neural crest migration. Cell 200I, I04(I):57-69.

35. Wang HU, Chen ZF, Anderson DJ: Molecular distinction and angiogenic interaction between embryonic arteries and veins revealed by ephrin-B2 and its receptor Eph-B4. Cell 1998, 93(5):74I-753

36. Chung M, Kizhatil K, Albritton LM, Gaulton GN: Induction of syncytia by neuropathogenic murine leukemia viruses depends on receptor density, host cell determinants, and the intrinsic fusion potential of envelope protein. I Virol 1999 , 73(I I):9377-9385

37. Koutsoudakis G, Herrmann E, Kallis S, Bartenschlager R, Pietschmann $\mathrm{T}$ : The level of CD8 I cell surface expression is a key determinant for productive entry of hepatitis $\mathbf{C}$ virus into host cells. J Virol 2007, 8 I (2):588-598.

38. Kuhmann SE, Platt EJ, Kozak SL, Kabat D: Cooperation of multiple CCR5 coreceptors is required for infections by human immunodeficiency virus type I. J Virol 2000, 74(I5):7005-70I5.

39. Kurre P, Kiem HP, Morris J, Heyward S, Battini JL, Miller AD: Efficient transduction by an amphotropic retrovirus vector is dependent on high-level expression of the cell surface virus receptor. J Virol 1999, 73(I):495-500.

40. Platt EJ, Wehrly K, Kuhmann SE, Chesebro B, Kabat D: Effects of CCR5 and CD4 cell surface concentrations on infections by macrophagetropic isolates of human immunodeficiency virus type I. J Virol I998, 72(4):2855-2864.

4l. Tailor CS, Nouri A, Kabat D: Cellular and species resistance to murine amphotropic, gibbon ape, and feline subgroup $C$ leukemia viruses is strongly influenced by receptor expression levels and by receptor masking mechanisms. J Virol 2000, 74(20):9797-980।

42. Vincent T, Pettersson RF, Crystal RG, Leopold PL: Cytokine-mediated downregulation of coxsackievirus-adenovirus receptor in endothelial cells. J Virol 2004, 78(I 5):8047-8058.

43. Willett BJ, Cannon CA, Hosie MJ: Upregulation of surface feline CXCR4 expression following ectopic expression of CCR5: implications for studies of the cell tropism of feline immunodeficiency virus. J Virol 2002, 76( I 8):9242-9252.

44. Dorig RE, Marcil A, Chopra A, Richardson CD: The human CD46 molecule is a receptor for measles virus (Edmonston strain). Cell 1993, 75(2):295-305.

45. Pasquale EB: Eph receptor signalling casts a wide net on cell behaviour. Nat Rev Mol Cell Biol 2005, 6(6):462-475.

46. Fuller T, Korff T, Kilian A, Dandekar G, Augustin HG: Forward EphB4 signaling in endothelial cells controls cellular repulsion and segregation from ephrinB2 positive cells. J Cell Sci 2003, I | 6:246|-2470

47. Holder N, Klein R: Eph receptors and ephrins: effectors of morphogenesis. Development 1999, I 26( I 0):2033-2044.

48. Kuijper S, Turner CJ, Adams RH: Regulation of angiogenesis by Eph-ephrin interactions. Trends Cardiovasc Med 2007, I7(5): $|45-| 5 \mid$.

49. Klein R: Eph/ephrin signaling in morphogenesis, neural development and plasticity. Curr Opin Cell Biol 2004, I 6(5):580-589.

50. Palmer A, Klein R: Multiple roles of ephrins in morphogenesis, neuronal networking, and brain function. Genes Dev 2003, I7( I 2): | 429-1450

5I. Song J, Vranken W, Xu P, Gingras R, Noyce RS, Yu Z, Shen SH, Ni F: Solution structure and backbone dynamics of the functional cytoplasmic subdomain of human ephrin B2, a cell-surface ligand with bidirectional signaling properties. Biochemistry 2002, 4 I (36): 10942-10949.

52. Cowan CA, Henkemeyer M: The SH2/SH3 adaptor Grb4 transduces B-ephrin reverse signals. Nature 200I, 413(6852): 174- 179 
53. Lu Q, Sun EE, Klein RS, Flanagan JG: Ephrin-B reverse signaling is mediated by a novel PDZ-RGS protein and selectively inhibits G protein-coupled chemoattraction. Cell 200I, I 05(I):69-79.

54. Lee B: Envelope-receptor interactions in Nipah virus pathobiology. Ann N Y Acad Sci 2007, I I 02:5 I-65.

55. Bossart KN, Crameri G, Dimitrov AS, Mungall BA, Feng YR, Patch JR, Choudhary A, Wang LF, Eaton BT, Broder CC: Receptor binding, fusion inhibition, and induction of cross-reactive neutralizing antibodies by a soluble $\mathbf{G}$ glycoprotein of Hendra virus. J Viro 2005, 79(II):6690-6702.

56. Levroney EL, Aguilar HC, Fulcher JA, Kohatsu L, Pace KE, Pang M, Gurney KB, Baum LG, Lee B: Novel innate immune functions for galectin-I: galectin-I inhibits cell fusion by Nipah virus envelope glycoproteins and augments dendritic cell secretion of proinflammatory cytokines. J Immunol 2005, I75(I):4I 3-420.

57. Corbeil J, Tremblay M, Richman DD: HIV-induced apoptosis requires the CD4 receptor cytoplasmic tail and is accelerated by interaction of CD4 with p56Ick. J Exp Med 1996, I 83(I):39-48

58. Davis CB, Dikic I, Unutmaz D, Hill CM, Arthos J, Siani MA, Thompson DA, Schlessinger J, Littman DR: Signal transduction due to HIVI envelope interactions with chemokine receptors CXCR4 or CCR5. J Exp Med 1997, I 86( I 0):1793-1798.

59. Breiner KM, Urban S, Glass B, Schaller H: Envelope protein-mediated down-regulation of hepatitis $B$ virus receptor in infected hepatocytes. J Virol 200I, 75(I): I43-150.

60. Choi B, Gatti PJ, Fermin CD, Vigh S, Haislip AM, Garry RF: Downregulation of cell surface CXCR4 by HIV-I. Virol J 2008, 5:6.

6I. Crise B, Buonocore L, Rose JK: CD4 is retained in the endoplasmic reticulum by the human immunodeficiency virus type glycoprotein precursor. J Virol 1990, 64(I I):5585-5593.

62. Fujisawa R, Masuda M: Ecotropic murine leukemia virus envelope protein affects interaction of cationic amino acid transporter I with clathrin adaptor protein complexes, leading to receptor downregulation. Virology 2007, 368(2):342-350.

63. Horga MA, Gusella GL, Greengard O, Poltoratskaia N, Porotto M, Moscona A: Mechanism of interference mediated by human parainfluenza virus type $\mathbf{3}$ infection. J Virol 2000 74(24): II792-1 I799.

64. Schneider-Schaulies J, Schnorr JJ, Brinckmann U, Dunster LM, Baczko K, Liebert UG, Schneider-Schaulies S, ter Meulen V: Receptor usage and differential downregulation of CD46 by measles virus wild-type and vaccine strains. Proc Natl Acad Sci USA 1995, 92(9):3943-3947.

65. Welstead GG, Hsu EC, lorio C, Bolotin S, Richardson CD: Mechanism of CDI50 (SLAM) down regulation from the host cel surface by measles virus hemagglutinin protein. J Virol 2004 78(18):9666-9674.

66. Sawatsky B, Grolla A, Kuzenko N, Weingartl H, Czub M: Inhibition of henipavirus infection by Nipah virus attachment glycoprotein occurs without cell-surface downregulation of ephrin-B2 or ephrin-B3. J Gen Virol 2007, 88:582-59I.

67. Henis YI, Herman-Barhom Y, Aroeti B, Gutman O: Lateral mobility of both envelope proteins ( $F$ and $H N$ ) of Sendai virus in the cell membrane is essential for cell-cell fusion. J Biol Chem 1989, 264(29): $17|19-17| 25$.

68. Hayashi S, Asahara T, Masuda H, Isner JM, Losordo DW: Functional ephrin-B2 expression for promotive interaction between arterial and venous vessels in postnatal neovascularization. Circulation 2005, I I I ( 7 7):2210-22/8.

69. le Noble F, Moyon D, Pardanaud L, Yuan L, Djonov V, Matthijsen R, Breant C, Fleury V, Eichmann A: Flow regulates arterial-venous differentiation in the chick embryo yolk sac. Development 2004, I3 I(2):36|-375.

70. Vihanto MM, Plock J, Erni D, Frey BM, Frey FJ, Huynh-Do U: Hypoxia up-regulates expression of Eph receptors and ephrins in mouse skin. Faseb / 2005, 19( I 2):|689-|69|

7I. Mungall BA, Middleton D, Crameri G, Bingham J, Halpin K, Russell G Green D, McEachern J, Pritchard LI, Eaton BT, et al.: Feline model of acute nipah virus infection and protection with a soluble glycoprotein-based subunit vaccine. J Virol 2006 , 80(24): $12293-12302$

72. Weingartl H, Czub S, Copps J, Berhane $Y$, Middleton D, Marszal $P$, Gren J, Smith G, Ganske S, Manning L, et al.: Invasion of the central nervous system in a porcine host by nipah virus. I Virol 2005 , 79(I 2):7528-7534

73. Moll M, Diederich S, Klenk HD, Czub M, Maisner A: Ubiquitous activation of the Nipah virus fusion protein does not require a basic amino acid at the cleavage site. J Virol 2004, 78(18):9705-97|2.

74. Maisner A, Mrkic B, Herrler G, Moll M, Billeter MA, Cattaneo R, Klenk HD: Recombinant measles virus requiring an exogenous protease for activation of infectivity. J Gen Virol 2000, 8I:44|-449.

75. Moll M, Kaufmann A, Maisner A: Influence of $\mathbf{N}$-glycans on processing and biological activity of the nipah virus fusion protein. J Virol 2004, 78(13):7274-7278.

76. Moll M, Klenk HD, Maisner A: Importance of the cytoplasmic tails of the measles virus glycoproteins for fusogenic activity and the generation of recombinant measles viruses. J Virol 2002, 76( I 4):7174-7|86.

77. Niwa H, Yamamura K, Miyazaki J: Efficient selection for highexpression transfectants with a novel eukaryotic vector. Gene 1991, 108(2):193-199.

78. Maisner A, Zimmer G, Liszewski MK, Lublin DM, Atkinson JP, Herrler G: Membrane cofactor protein (CD46) is a basolateral protein that is not endocytosed. Importance of the tetrapeptide FTSL at the carboxyl terminus. J Biol Chem 1997, 272(33):20793-20799.

79. Whitman SD, Dutch RE: Surface density of the Hendra G protein modulates Hendra $F$ protein-promoted membrane fusion: role for Hendra $G$ protein trafficking and degradation. Virology 2007, 363(2):419-429.

80. Reed LJ, Muench $\mathrm{H}$ : A simple method of estimating fifty per cent endpoints. J Hyg 1938, 27:493-497.
Publish with Biomed Central and every scientist can read your work free of charge

"BioMed Central will be the most significant development for disseminating the results of biomedical research in our lifetime. "

Sir Paul Nurse, Cancer Research UK

Your research papers will be:

- available free of charge to the entire biomedical community

- peer reviewed and published immediately upon acceptance

- cited in PubMed and archived on PubMed Central

- yours - you keep the copyright
BiolMedcentral 